\title{
Taşradan Dersaadet'e Uzanan Bir Zincir: Osmanlı Devleti’nde 1846 Sonrası Ceza Jurnalleri
}

\section{A Chain Extending from the Periphery to Dersaadet: Criminal Journals in the Ottoman Empire after 1846}

\author{
Kübra Nugay $^{1}$ (D)
}

${ }^{1}$ Sorumlu yazar/Corresponding author: Kübra Nugay (Bağımsız araştırmacı), İstanbul, Türkiye

E-posta:kbr_ngy@hotmail.com

ORCID: 0000-0002-0773-0335

Başvuru/Submitted: 31.07 .2021 Revizyon Talebi/Revision Requested: 11.08.2021

Son Revizyon/Last Revision Received: 18.08.2021

Kabul/Accepted: 23.08 .2021

Atıf/Citation: Nugay, Kübra. Taşradan Dersaadet'e Uzanan Bir Zincir: Osmanlı Devleti'nde 1846 Sonrası Ceza Jurnalleri. Islam Tetkikleri Dergisi-Journal of Islamic Review 11/2, (Eylül 2021): 913-939.

https://doi.org/10.26650/iuitd.2021.977134

\section{ÖZ}

1839 tarihinde Tanzimat Fermanı́nın ilanından sonra Osmanlı Ceza Hukukunda iki önemli değişim dikkat çekmektedir. Bunlardan birincisi, 1840 tarihli Ceza Kanunu ile başlayan kanunlaştırma çalışmaları (1840 tarihli Ceza Kanunu'nu daha sonra 1851 ve 1858 tarihli Ceza Kanunları izlemiştir), ikincisi ise ceza kanununda belirtilen suçlara dair ceza davalarının Şeriat Mahkemeleri'nden ayrı, taşrada kurulan meclislerde görülmeye başlanmasıyla taşradan merkeze uzanan aşamalı yeni bir ceza yargılama sisteminin inşa edilmesidir (Nitekim bu yeni ceza yargılama sistemi 1864 tarihinde kurulan Nizamiye Mahkemelerine zemin teşkil etmiştir). Ceza hukuku alanında yaşanan bu önemli değişimler detayda birçok değişimi de beraberinde getirmiştir. Suç işleyen kimselerin isimlerinin, suçlarının ve suça dair davalarının görüldüğü meclis tarafından takdir edilen cezalarının bendler halinde yazıldığı ceza jurnalleri bunlardan biridir. Bu çalışmada, ilk olarak Tanzimat sonrası düzenlenmeye başlanan ceza jurnallerinin tarihi sürecine, yapısal özelliklerine, önemli değişimler yaşayan ceza hukuku içerisindeki işlevine odaklanılacaktır. Esasında 1840 sonrası dönemde yaşanan değişimin küçük bir unsuru olan ceza jurnallerinden yola çıkarak bu dönemde Osmanlı Ceza Hukukunun yaşadığı büyük değişimi anlamak için farklı bir yöntem denenecektir.

Anahtar Kelimeler: İslam Hukuku, Osmanlı Ceza Hukuku, Tanzimat Dönemi, Değişim, Merkezileşme, Jurnal

\section{ABSTRACT}

Two critical changes are remarkable in Ottoman criminal law after the proclamation of the Tanzimat Edict in 1839. The first of these is the codification studies that started with the Penal Code of 1840 (followed by the 1851 and 1858 Penal Codes). The second is the formation of a new criminal jurisdiction system, which gradually extends from the periphery to the center. Penal Code-defined criminal cases started to be heard in the councils established in the periphery, separate from sharia courts. (Thus, this new criminal jurisdiction system formed the basis for the Nizamiye courts, established in 1864.) These critical changes in the area of criminal law have 
brought many changes in detail. One such change is the criminal journals, in which names of offenders, their crimes, and the punishments determined by the councils where the criminal case is heard were written in paragraphs. This study focuses on the historical process and the structural features of criminal journals, initially written after the Tanzimat (by the councils), and their function in criminal law, having experienced crucial changes. Different methods will be tried, such as understanding the significant changes experienced in Ottoman criminal law in this period, starting with the criminal journals, which are a limited element of the change experienced in the post-1840 period.

Keywords: Islamic Law, Ottoman Criminal Law, Tanzimat Era, Transformation, Centralization, Journal

\section{EXTENDED ABSTRACT}

The Ottoman Empire witnessed a significant transformation in criminal law after the proclamation of the Gülhane Imperial Edict dated November 3, 1839. This transformation falls under two main headings: (1) the codification in the field of criminal law and (2) the new criminal jurisdiction system formation. These two impactful changes in the field of criminal law since 1840 mentioned above have led to the restructuring of many institutions, structures, and assignments belonging to the classical period. They also led to the formation of new unprecedented implementations. We will attempt to understand the significant change in Ottoman criminal law through the changes experienced by one element in the process. In addition, we will also see the point reached by Ottoman criminal law in the first quarter of the 20th century was the end point that the criminal law system, which started after the Tanzimat and consisted of many interconnected elements, came over a long period. We will address when and how the criminal journals were prepared, how they were delivered from the periphery to the center and their function in the new criminal jurisdiction system after 1840 . We will also discuss why these journals were necessary. As far as we know, there has never been an independent study on criminal journals, which were seen first in the post-Tanzimat period. The only person who has mentioned them in the domestic and foreign literature is Sedat Bingöl. Sedat Bingöl mentioned these journals, albeit briefly, in his work on the Nizamiye courts, but did not give detailed information or examples on their features. Therefore, we believe this study makes a significant contribution to the relevant literature. It provides detailed information on the criminal journals implemented for the first time in the Ottoman criminal law after 1840 and thus enabling a better understanding of criminal law of that period. 


\section{Giriş}

Osmanlı Devleti, 3 Kasım 1839 tarihli Gülhâne Hatt-1 Hümâyûnu’nun ilanından sonra ceza hukuku alanında önemli ölçüde değişime sahne olmuştur. Bu değişimi genel olarak iki ana başlıkta sunmak mümkündür. Bunlardan ilki ceza hukuku alanında kanunlaştırmaya gidilmesi, ikincisi ise yeni bir ceza yargılama sisteminin kurulmasıdır. Tanzimat Fermanı'nın mukaddemesinde, yüz elli senedir devletin zaaf ve fakr içinde bulunduğu ve bunun sebebi olarak şer'-i şerîf ve kanûn-ı münîfe imtisâl olunmaması gösterilmiş ve bu durumdan kurtulmak için çarenin kavânîn-i cedîde vaz' etmek olduğu ifade edilmişti. Fermanın içeriğinde vaz' edilecek yeni kanunlarda yer alacak maddeler emniyet-i can, mahfûziyet-ı ırz u nâmûs u mâl ve ta'yîn-i vergi ve asâkîr-i mukteziyyenin sûret-i celb ve müddet-i istihdâmı şeklinde beş ana başlıkta toplanmıştır. ${ }^{1}$ Fermana göre bu kanunî düzenlemeler yapılmadıkça devletin eski kuvvetini elde etmesi, huzura kavuşması, asayişi sağlaması mümkün olmayacaktır. Fermanın devamında bu kanunların din, devlet ve milletin ihyası için vaz' olunacağı, bu nedenle gerek Padişah tarafından gerekse dönemin ulema ve vekilleri tarafından kanunun hilâfına hareket edilmeyeceğine dair Hırkâ-i Şerif odasında söz verildiği ifade edilmiş, eğer hilâfına hareket eden olur ise "kabahat-1 sâbitelerine göre te' dîbât-1 lâyıkalarının hiç rütbeye ve hatır ve gönle bakılmayarak icrâsı zımnında mahsûsan cezâ kânunnâmesi dahi tanzîm ettirilsin” denilerek tanzim edilecek ceza kanununa göre cezalandırılacakları söylenmiştir. ${ }^{2}$ Yaklaşık altı ay sonra 3 Mayıs 1840 (Gurre-i Rebîülevvel 1256) tarihinde fermanda çare olarak görülen kanunnamenin hazırlandığı görülür, dikkat çeken nokta ise fermanda ele alınan beş madde (askere alma ile ilgili düzenleme hariç) birleştirilerek tek bir kanun olarak ceza kanunu halinde düzenlenmiş olmasıdır. Bu durum, birçok konuya dair düzenlemeleri içeren Osmanlı kanunname ${ }^{3}$ geleneğinin bir tezahürü olarak görülebilir. ${ }^{4}$ Ancak bu son kanunu, kanunname geleneğinden ayıran önemli bir fark vardır: Bir "ceza” kanunu olarak düzenlenmesidir. Bu farklılığın cevabını, Osmanlı Devleti’nin kendi iç sebeplerinde ve ihtiyaçlarında aramak gerektiği gibi, kendi sınırlarının dışında diğer ülkelerde yaşanan benzer süreçlerde de aranmalıdır. ${ }^{5}$ Nitekim ceza

1 Bakınız: Gülhâne Hatt-1 Hümûyûnu, Düstûr I. Tertip (Dersaadet, Matbaa-i Âmire, 1282), 4.

2 Gülhâne Hatt-1 Hümûyûnu, Düstûr I. Tertip, 4.

3 Uriel Heyd, "Eski Osmanlı Ceza Hukukunda Kanun ve Şeriat”, Türk Hukuk ve Kültür Tarihi Üzerine, trc.: S. Eroğlu (Ankara: Ankara Okulu, 2014), 49-72.

4 Kanunnamenin içeriğine bakıldığında dikkat çeken en önemli husus, Tanzimat ile yapılan düzenlemelerin kanunnamede maddeler halinde verilmesi ve maddelerin altında bu düzenlemelere muhalif hareket edenlere ceza tayin edilmesidir. Aslında böylece yeni suç tanımları yapılmış, suç alanı genişletilmiştir. Ama buradan çıkarılacak asıl sonuç, yapılan düzenlemelerin kanunname haline getirilmesi Osmanlı kanunname geleneğini yansıtan bir durum olması ile birlikte kanunnamenin bir "ceza" kanunu adıyla ve içeriğinde ele alınan düzenlemelerin yaptırıma bağlanarak ifade edilmesidir. Bu durum Osmanlı kanunname geleneğinde olmayan yeni bir uygulamaydı.

5 Esasında bu yüzyılda birçok ülkede olan şuydu: Devlet tarafından çeşitli gerekçelerle yapılan önemli düzenlemelerin itirazsız uygulanabilirliğini sağlamak için aksine hareket edilmesi halinde uygulanacak cezaî yaptırımlara başvurmaktı. Osmanlı Devleti de Tanzimat ile birçok alanda başlattı̆̆ı düzenlemelerin, itiraz edilmeden uygulanmasını sağlamak için cezaî yaptırımdan faydalanacaktır. 1840 yılında hazırlanan Ceza Kanunu ve arka planı hakkında daha ayrıntılı bilgi için bakınız: Kübra Nugay, XIX. Yüzyıl Ortak Ceza Hukuku Dilinin Oluşumu: Osmanlı'da Ta 'zîrin Kalkması (İstanbul: Marmara Üniversitesi Sosyal Bilimler Enstitüsü, Doktora Tezi, 2020), 11-61. 
alanında kanunlaştırmaya gidilmesinin arkasında yatan sebep tamamen Osmanlı'ya özgü olsa da form olarak XVIII. yüzyıldan itibaren özellikle İngiltere ve Fransa başta olmak üzere dönemin önemli güçlerinin sömürgelerinde ceza alanında kanunlaştırmaya gitmeleri ve yeni ceza yargılama sistemi kurmaları konusundaki benzerlik dikkat çekicidir. 1840 Ceza Kanunu ile amaç, içeriğindeki maddeler ve dönemin şartları birlikte değerlendirildiğinde Tanzimat ile birçok alanda yapılan yeni düzenlemeleri korumak ve muhafaza etmekti. 1840 tarihli Ceza Kanûnnâme-i Hümâyûnu'nu 1851 tarihli Kanûn-1 Cedîd izlemiş, son olarak bu iki ceza kanununu ilga eden ve onların amacından tamamen farklı 1858 tarihli Ceza Kanûnnâme-i Hümâyûnu vaz' edilmiştir.

Tanzimat sonrası Osmanlı Ceza Hukuku alanında görülen ikinci önemli değişim 1840 yılından itibaren Dersaadet'te Meclis-i Vâlâ, taşrada ise meclislerden oluşan yeni bir ceza yargılama sisteminin oluşmasıdır. Esasen bu yargılama sistemi, yeni oluşturulan idarî teşkilatın içerisine yerleştirilmiş, Şeriat Mahkemesi bünyesinden ayrı, ancak davaların muhassıl, mal müdürü, kocabaşı, metropolit gibi birçok farklı kişiden oluşan meclis üyeleri önünde marifet- $i$ şer 'l $e^{6}$ görüldüğü, kendine has vaz' edilmiş ceza kanunlarına göre hükmün verildiği, ${ }^{7} 1864$ yılında kurulacak olan Nizamiye Mahkemesi sisteminden farklı ancak bu mahkemelerin kurulması için de yolu açan bir yapıya sahipti. 1840 ve daha sonra 1851 tarihli Ceza Kanunlarında tanımlanmış suçlara dair davalarının görüldüğü bu meclislerde gerek davaların görülme şekli gerekse karara bağlanma sürecinde birçok yeniliğe ve değişime, hiyerarşik ve aşamalı bir ceza yargılama sistemine şahit olunmuştur. Nitekim bu yap1 1864 tarihinde Vilâyet Nizamnâmesi ile Nizamiye Mahkemeleri kurulana kadar devam etmiştir. Nizamiye Mahkemeleri kurulduktan sonra ise o dönem yürürlükte olan 1858 tarihli Ceza Kanunu burada görülen davalarda uygulanmıştır.

1840 yılından itibaren ceza hukuku alanında yukarıda işaret edilen bu iki önemli değişim, klasik döneme ait birçok yapı, kurum ve görevlerin de değişerek yeniden tanımlanmasına, yeni görev ve uygulamaların oluşumuna neden olmuştur. Bu çalışmada, bu yeni uygulamalardan biri olan ve Tanzimat sonrası ceza hukuku alanında daha önce var olmayan ceza jurnallerine odaklanarak detayda yer alan bir unsurun süreç içerisinde yaşadığı değişim üzerinden Osmanlı Ceza Hukukunun geçirdiği büyük değişim anlaşılmaya çalışılacaktır. Ayrıca Osmanlı Ceza Hukukunun XX. yüzyılın ilk çeyreğinde ulaştığı noktanın, Tanzimat sonrası başlayan ve birbiriyle bağlantılı birçok unsurdan oluşan ceza hukuku sisteminin, uzun bir sürecin sonunda değişerek geldiği son nokta olduğu görülecektir. Bu bağlamda, ceza jurnallerinin ne zaman ve nasıl hazırlandı ̆̆ 1 , hangi basamaklardan geçerek merkeze ulaştırıldığ 1,1840 sonrası uygulamaya konulan yeni ceza yargılama sistemi içerisindeki yeri ve bu jurnallere neden ihtiyaç duyulduğu

61840 Ceza Kanûnnâme-i Hümâyûnu 1. Fasıl, 4. Madde.

7 Kanunun nerelerde uygulanacağı, 1840 tarihli Ceza Kanununa dair hatt-1 hümâyûnda işaret edilmiştir: “...kâffe-i mehâkimde ve Memâlik-i Devlet-i Aliyyemizin meşveret meclislerinde ve sâir iktizâ iden yerlerde bulunup da mevâdd-1 kanûniye ve nizâmiyede ona mürâcaat olunmak lâzım geleceğinden bu hususun dahi icrâ-yı iktizâsına ibtidâr olunsun ve bazı zeyl ve ilâvesi muktezi olan şeyler oldukça onun dahi îcâbına bakılsın". Ceza Kanunname-i Hümâŷ̂nu, (İstanbul: Süleymaniye Yazma Eserler Kütüphanesi, Esad Efendi, 1877). 
gibi konular ele alınacaktır. Esasında jurnal denildiğinde ilk akla gelen II. Abdülhamid döneminde çeşitli kesimler hakkında istihbarat ve gizli bilgi toplamak ise $\mathrm{de}^{8}$ jurnal ve hatta jurnal defterleri ifadelerinin bu anlamdan farklı olarak Tanzimat'ın ilanından önce de birçok amaçla çeşitli birimlerden merkeze gönderilen bilgilendirme yazılarını ifade etmek için kullanıldığı görülür. ${ }^{9}$ Cumhurbaşkanlığı Osmanlı Arşivi belgeleri arasında Tanzimat'ın ilanından sonrası için yaptığımız taramada bazı zabıta vukuatlarının, kazalarda meydana gelen vukuatların, doğanların-ölenlerin, evlenenlerin, gelip-gidenlerin yazıldığı, Anadolu'dan ve Rumeli'den Dersaadet'e gelen ve taşraya giden kişilerin isimlerinin kaydedildiği, çeşitli tayinlerin kaydının tutulduğu, kahvehanelerde söylenen ve halk arasında dolaşan bazı dedikoduların yazıldığı, Bâb-1 Seraskerî’den, İhtisâb'dan, Bâb-1 Müşîr'den, Meclis-i Tahaffuz'dan, Karantina Nezareti tarafından çeşitli hadiselerin mutad şekilde yazılarak Sadarete gönderildiği yazılar için de jurnal ifadesinin kullanıldığı görülmüştür. ${ }^{10}$ Tanzimat sonrası hazırlanan bu tarz jurnallerle ilgili olarak Cengiz Kırlı, İ. Hakkı Aksoyak, Abdülkerim Abdülkadiroğlu tarafından çeşitli çalışmalar hazırlanmıştır, ancak bu konuda arşiv belgelerini kullanarak ve pratik uygulamadan da faydalanarak yapılan en detaylı teorik çalışmanın Mehmet Zahit Yıldırım tarafından yapıldığı söylenebilir. Bu eserde jurnal, 1835 tarihinde II. Mahmud tarafindan kurulan Jurnal Teşkilatının görevlilerinin bulundukları yerleşim biriminde meydana gelen günlük hayatın her alanına ait bilgilerin kaydedildiği defterler olarak tanımlanmıştır. Teşkilatın kurulma amacı, memleketin ve milletin nizam ve düzeninin sağlanmasının halkın refah içerisinde bulunmasına bağlı olduğu, refah içerisinde olmayanların da durumlarının bilinmesi gerektiği şeklinde açıklanmıştır. Kaza, sancak ve eyaletlerde maaşlı jurnal katipleri görevlendirilmiş, bu katipler gerek resmî kurumlardan aldıkları bilgileri gerekse gördükleri-duydukları bilgileri bu defterlere kaydetmiş ve merkeze sunmuşlardır. ${ }^{11}$

8 Bu konuda yapılan çalışmalardan birkaçı şu şekildedir: Reşat Koçu, Tarihimizde Garip Vakalar (İstanbul: Doğan Kitabevi, 2005); Faiz Demiroğlu, Abdülhamid'e Verilen Jurnaller (50 Yıldır Neşredilmeyen Vesikalar) (İstanbul: Tarih Kütüphanesi, 1955); Süleyman Kani İrtem, Abdülhamid Devrinde Hafiyelik ve Sansür, haz: Osman Selim Kocahanoğlu (İstanbul: Temel Yayınları, 1999); Mehmet Ali Beyhan, II. Abdülhamid Döneminde Hafiye Teşkilatı ve Jurnaller, Türkler (Ankara: Yeni Türkiye Yayınları, 2002), 12/940.

9 Örneğin; İstanbul'da çeşitli semtlerde çıkan yangınlara dair ihbar jurnalleri için bakınız: Cumhurbaşkanlığı Osmanlı Arşivi (BOA), Topkapı Sarayı Müze Arşivi (TS.MA.e), No. 700, Gömlek No. 19; Girid'e ait jurnaller için bakınız: Cumhurbaşkanlığı Osmanlı Arşivi (BOA), Hatt-ı Hümayûnu (HAT), No. 394, Gömlek No. 20829; Dersaadet ve bilâd-ı selase nüfusunun bir aylık jurnali için bakınız: Cumhurbaşkanlığı Osmanlı Arşivi (BOA), Hatt-ı Hümayûnu (HAT), No. 1268, Gömlek No. 49090; İstanbul' da bulunan asâkir-i muntazama alaylarına dair jurnaller için bakınız: Cumhurbaşkanlığı Osmanlı Arşivi (BOA), Cevdet-Maliye (C..ML..), No. 375, Gömlek No. 15435.

10 Bu konuda daha fazla ayrıntı için Cumhurbaşkanlığı Osmanlı Arşivi’nde "jurnal” kelimesi ile tarama yapmak yeterli olacaktır.

11 Mehmet Zahit Yıldırım, Osmanlı Devleti’nde Jurnal Teşkilatı (İstanbul: AKY Basım, 2012), 1-18, 85-93; Cengiz Kırlı, Sultan ve Kamuoyu, Osmanlı Modernleşme Sürecinde "Havadis Jurnalleri” (1840-1844) (İstanbul: Türkiye İş Bankası, 2009), 1-13; Cengiz Kırlı, “Kahvehaneler ve Hafiyeler: 19. Yüzyıl Ortalarında Osmanlı’ da Sosyal Kontrol”, Toplum ve Bilim 83 (1999/2000), 58-79; Kastamonu jurnal defteri (1254-1255/1838-1839): Metin ve Tıpkıbasım, haz. Abdulkerim Abdulkadiroğlu, İ. Hakkı Aksoyak, Necip Fazil Duru, (Ankara: Başbakanlık Devlet Arşivleri Genel Müdürlüğü, 1998). 
İlk defa Tanzimat sonrası dönemde rastlanan ceza jurnalleri hakkında bildiğimiz kadarıyla şimdiye kadar müstakil bir çalışma olmayıp, yerli ve yabancı literatürde bu konuya değinen tek kişi Sedat Bingöl'dür. Sedat Bingöl Nizamiye Mahkemeleri ile ilgili çalışmasında kısa da olsa bu jurnallere değinmiş, ancak mahiyeti hakkında detaylı bilgi ve örnek vermemiştir. ${ }^{12}$ Dolayısıyla bu çalışmanın, gerek 1840 sonrası Osmanlı Ceza Hukukunda ilk defa uygulanan ceza jurnalleri hakkında ayrıntılı bilgi sunacak olması ve gerekse özellikle bu şekilde jurnallerin hazırlanma gerekçelerinin işaret ettiği gerçeğin dönemin ceza hukukunu daha iyi anlama konusunda 1 şık tutacak olması gibi nedenlerden dolayı ilgili literatüre önemli bir katkı sunacağı kanaatindeyiz.

\section{Yeni Bir Usul: Ceza Jurnallerinin Tarihi ve Yapısı}

Osmanlı Ceza Hukukunda Tanzimat'ın ilanından sonra başlayan kanunlaştırma ve Şeriat Mahkemeleri'nden ayrı yeni bir ceza yargılama sistemi inşa edilmesi şeklinde görülen önemli ve büyük değişim, içerisinde birçok detay unsurun da değişimini ve yeniden yapılandırılmasını ya da yeni birçok unsurun oluşumunu beraberinde getirmiştir. Bu yeni unsurlardan biri olan ceza jurnalleri üzerinden Osmanlı Ceza Hukukunun geçirdiği büyük değişime dair bir fikir edinmeyi amaçlayan bu çalışmada ceza jurnallerinin içeriğini ve şekilsel özelliğini anlamakla işe başlanacaktır. Ceza Jurnallerinin Dersaadet'te ve taşrada farklı zaman dilimlerinde hazırlanmaya başlanması, ayrıca farklı meclisler tarafından hazırlanarak farklı aşamalardan Meclis-i Vâlâ'ya gönderilmesi nedenlerinden dolayı ayrı başlıklarda ele alınacaktır.

\subsection{Dersaadet'te Hazırlanan Ceza Jurnali}

Suç işleyen kimselerin isimlerinin, suçlarının ve suça dair davanın görüldüğü meclis tarafından takdir edilen cezasının bendler halinde yazıldığı jurnallere ilk olarak 1846 (h.1262) senesinde Dersaadet'te rastlanmaktadır. Dersaadet'te bu süreçte var olan ceza yargılama sistemine bakıldığında, 1840 tarihi sonrası taşrada kurulan meclis sisteminden farklı ancak benzer şekilde aşamalı ve Şeriat Mahkemeleri'nden ayrı olması bakımından yine benzer bir yapının inşa edildiği görülecektir. ${ }^{13} 1846$ 'da Dersaadet'te Zaptiye Müşirliği ve bunun çatısı altında Zaptiye Meclisi kurulmuş ve bu yapı 1864'e kadar devam etmiştir. Esasında bu sürecin de kendi içerisinde iki evreye ayrıldığı görülmektedir: 1854'e kadar devam eden Zaptiye Meclisi

12 Sedat Bingöl, Tanzimat Devrinde Osmanlıda Yargı Reformu: Nizamiye Mahkemelerinin Kuruluşu ve İşleyişi 1840-1876 (Eskişehir: Anadolu Üniversitesi Edebiyat Fakültesi, 2004), 68.

13 1846'dan sonra Dersaadet'te işlenen bir katl suçunun muhakemesi ve hükme bağlanma aşamaları ise şu şekildedir: 1-Zaptiye Meclisi'nde (1854'ten sonra Meclis-i Tahkik'te) suçluların istintâk ve muhakemelerinin yapıldığı, ceza süresini bildiren i'lâm ve mazbatanın hazırlandığı,

2-Hazırlanan i'lâm ve mazbatanın Meclis-i Vâlâ'ya gönderildiği,

3-Meclis-i Vâlâ'ya gelen i'lâm ve mazbatanın görüşülerek dava hakkında karar ve hükmün verildiği,

4-Verilen hükmün Sadarete gönderildiği ve burada onaylandığı (bazen çeşitli sebeplerden dolayı onaylanmadığı da görülür)

5- Sadaretten aynı yol ile aynı basamaklardan sırayla yazışmalar yapılarak hükmün mahalline bildirildiği görülür. Ayrıntılı bilgi için bakınız: Kübra Nugay, XIX. Yüzyıl Ortak Ceza Hukuku Dilinin Oluşumu: Osmanlı'da Ta'zîrin Kalkmas1, 81-84. 
bu tarihte kapanarak yerine başka bir meclis açılmıştır. 1846 tarihine kadar Dârü'l-Hilâfeti'lAliyye muhafızlığına verilen bu görev, askerî memurları fazlaca meşgul etmesi nedeniyle görevlerini ertelemelerine neden olmuş, bundan dolayı bu iki görevin birbirinden ayrılması gerektiğine karar verilmiştir. Böylece 1846 yılında Zaptiye Müşirliği ${ }^{14}$ yine aynı yıl Zaptiye Müşirliğine bağlı olarak Dersaadet'te Zaptiye Meclisi kurulmuştur. ${ }^{15}$ Bu meclis 1854 yılına kadar görevine devam etmiş, bu tarihte lağvedilerek yerine Zaptiye Nezareti'ne bağlı iki meclis kurulmuştur. ${ }^{16}$ Bunlardan ilki Divân-ı Zaptiye olup bu meclis, her türlü kabahat ve cünhanın, üç ay hapis veya on mecidiye altın para cezası alınacak derecedeki davaların muhakemesini yapmakla ve bunların hükmünü vermekle görevliydi. İkinci meclis olan Meclis-i Tahkik ise Divan-ı Zaptiye'ye havale olan davaların üzerindeki cünha ve her türlü cinâyât davalarının yalnız tetkik ve muhakemesini yapmakla görevliydi, hüküm için dava i'lâm ve mazbataları Meclis-i Vâlâ'ya havale ederdi. ${ }^{17}$ Nizamiye Mahkemeleri kurulana kadar da bu iki mahkeme Dersaadet'te görevlerine devam etmişti. ${ }^{18}$ Ceza yargılamasındaki değişime bakıldığında tarihî olarak bu süreçlerden geçen Dersaadet'te bir kimse suç işlediğinde davası Zabtiye Meclisi'nde görülürdü. Her bir davanın süreci işlenen suçun büyüklüğüne göre farklı aşamalardan geçerek hükme bağlanmaktaydı. Ancak Zabtiye Meclisi’nde aynı tarih aralığında görülen tüm davalar jurnal halinde hazırlanarak Zabtiye Müşiri'ne oradan da Meclis-i Vâlâ'ya gönderilmekteydi. Suçluların isimlerinin, işledikleri suçların ve buna dair verilen hükümlerin kaydedildiği bir ceza jurnali ile kastedilen şudur:

1- Jurnalin başında -genelde- Meclis-i Zabtiye'de görülen ve jurnalin içeriğinde bulunan davaların tarihlerini içine alan genel bir tarih aralığını bildiren yazı yer almaktadır.

2- Dersaadet'in çeşitli mahallerinde işlenen suçlar ve bu suçları işleyen kimselerin isimleri siyah yazı ile bendler halinde yazılmaktadır.

3- Her bir bendin üzerinde suçlu hakkında verilen hüküm kırmızı ve eğik bir yazı ile yazilmaktadır.

4- Jurnalin sonunda üst makama hitaben jurnalin sunulduğunu belirten bir yazı, jurnalin hazırlandığı tarih ve Umûr-1 Zabtiye Meclisi mührü yer almaktadır.

Dersaadet’te Zabtiye Meclisi'nde hazırlanan bir jurnal örneği şu şekildedir:

14 Takvîm-i Vekâyi, (18 Safer 1262/1846), 297.

15 Takvîm-i Vekâyi, (22 Rebîülevvel 1262/ 1846), 300.

16 Zabtiye Meclisi'nin lağv edilmesinin sebebi; kurulan meclislerde kimsenin haksızlığa uğratılmaması için Meclis-i Âli-i Tanzimat tarafından bir Muhâkemât Nizamnamesi hazırlanmakta olduğu ancak bunun henüz tamamlanmasının zaman alacak olması, aynı zamanda bir kabahat işleyen ile katil ve hırsızların Bâb-1 Zabtiye'de aynı hapishanede bulundurulmaları, ayrıca cezası gereği birkaç gün hapis cezasına müstahak olanların istintak ve muhakemelerinin icrasına kadar birkaç ay hapiste beklemek zorunda olmaları gibi nedenlerle uzun zamandır bilinen ve zabtiye müşiri tarafindan da defaatle dile getirilen bu gibi sorunlara acilen tedbir alınması gerektiğinden Zabtiye Meclisi'nin ilgasıyla bu iki meclisinin açılmasına karar verilmiştir. Osman Nuri Ergin, Mecelle-i Umur-l Belediye: Tarih-i Teşkilat-ı Belediye (İstanbul: Matbaa-i Osmaniye, 1922), 890.

17 Osman Nuri Ergin, Mecelle-i Umur-l Belediye, 890-891.

18 E. Engelhardt, Tanzimat ve Türkiye, çev. Ali Reşad (İstanbul: Kaknüs Yayınları, 1999), 60; J.H.A. Ubicini, Türkiye 1850 (İstanbul: Tercüman Gazetesi, 1977), 170. 
Jurnalin üst yazısl: "İki yüz altmış iki senesi mâh-1 cemâziyelevvelin yirmi üçüncü salı günü zîrde muharrerü'l-esâmî eşhâsın mürtekib oldukları töhmet ve cünhalarına mebnî ahz ü kirfet olunarak Bâb-1 Zabtiyeye bi'l-vürûd meclisce fasl ve ru'yet kılınan keyfiyet-i vâkıa ve husûsât-1 sâirelerini mübeyyin hülâsa vechle defteridir ki ber vech-i atî zikr ü beyân k1lınur." (Siyah yazı ile yazımıştır.)

Bend halinde yazılan suç ve suçlunun ismi: "Mevlevîhâne kapusı civârında Mimâr Sinân mahallesi sâkinlerinden Bekçi Mustafa ve kayın birâderi Sadullah ahz ü i’tâdan dolayı birbirleriyle münâzaa itmiş olduklarından ahâli-i mahalle karavula virüb göndermiş olduğu." (Siyah yazı ile yazılmıştır.)

Davanın hükmü: "Huzûr-1 Şer'-i şerîfe bi'l-irsâl beynleri bulunarak saluverilmiş olduğu." (Bendin üst kısmında, eğik ve kırmızı yazı ile yazılmıştır.)

Diğer bir bendde yer alan suç ve suçlunun ismi: 'Üsküdar'da Şemsipaşa'da sâkin tebaadan Hâfız Ağa medîne-i mezkûrda Şeyh Câmii civârında Aişe Hatun'un hanesine girmiş olduğunu gece saat iki karârlarında ahâli-i mahalle bâsub göndermiş olduğu." (Siyah yazı ile yazılmıştır.)

Davaya ait hüküm: "Ta'zîr-i şer'î bi'l-icrâ sebîl-i tahliye kılınmış olduğu” (Bendin üst kısmında, eğik ve kırmızı yazı ile yazılmıştır.) $)^{19}$

Jurnalin sonunda yer alan yazı: "Bâlâda bend bend beyân olunan husûsât Bâb-1 Zabtiye'de tarîh-i mezkûrda vukua gelen mesâlih olduğundan keyfiyet ma'lûm-1 âlîleri buyurulmak üzere işbu mahâl-i şer'e bildirilüb temhir bulunduğu." (23 Cemâzilevvel 1262, Umûr-1 Zabtiye Meclisi mührü- Siyah yazı ile yazılmıştır.) ${ }^{20}$ (Jurnal için bakınız: Ek-1.)

Bâb-1 Zabtiye'den gönderilen jurnallerin hemen hepsinde yukarıda zikredilen şekilsel özelliklere dikkat edildiği gözlemlenmiştir.

\subsection{Taşradan Gönderilen Ceza Jurnali}

Dersaadet'te uygulanan ceza jurnali usulü, 1849 yılında düzenlenen Eyâlet Meclisleri Nizâmnâmesi ${ }^{21}$ ile taşrada yer alan meclislerde de uygulanmaya başlanmıştır. Tanzimat sonrası taşrada 1840 yılında Muhassıllık Meclisleri adında inşa edilen ve çeşitli suçlara ilişkin davaları görme yetkisi de verilen bu meclisler, iki yıl sonra 1842 yılında muhassıllığın kaldırılarak iltizama dönüştürülmesi ile ismi Memleket Meclisleri olarak değiştirilmiş, bu meclislerin adı değiştirilse de ceza davalarını görme yetkisi devam etmiştir. Zamanla uygulamada çıkan bazı sorunlar

19 Jurnalde yukarıda ifade edilen iki bend haricinde birçok bend ve üzerlerinde hükümleri vardır. Burada örnek olması açısından ilk iki bend ve hükmü yukarıda ifade edilmiştir.

20 Cumhurbaşkanlığı Osmanlı Arşivi (BOA), Sadâret-Mektûbî Evrakı (A.\}MKT.), No. 42, Gömlek No. 52, 2; Benzer bir jurnal için bakınız: Cumhurbaşkanlığı Osmanlı Arşivi (BOA), Cevdet-Zabtiye (C..ZB..), No: 72, Gömlek No: 3586,1 .

21 Bu nizamnameyle birlikte umumî bir talimatname ve tüm memurlara, umûr-1 mülkiye ve zaptiye memurlarına, mal memurlarına, hükkâm-1 şer'e, meclis azalarına, kaza müdürlerine ayrı ayrı yeni talimatnameler hazırlanarak görevleri ayrıntılı şekilde tarif edilmiştir. (Nizâmnâmenin tam metni için bakınız: Cumhurbaşkanlığg Osmanlı Arşivi (BOA), Bâb-ı Âsâfî- Divân-ı Hümâyûn Sicilleri Nizâmât Defterleri (A.(DVNSNZAM.d), No.00044, 56-75. Bu talimatnameler ve meclis nizamnamesi 1864 yılında çıkarılan Vilayet Nizamnamesine kadar geçerli olmuştur. Musa Çadırcı, Tanzimat Sürecinde Türkiye Ülke Yönetimi (İstanbul: İmge Yayınevi, 2017), 62. 
nedeniyle o zamana kadar taşra teşkilatında yapılan değişikler ve görülen eksiklikler 1849 senesinde hazırlanan Eyâlet Meclisleri Nizâmnâmesi ile yeniden düzenlenmişti. Nizâmnâmenin "Umûr-1 zâbıta ve kanûniyeye dâir mevâddır" adlı Fasl-1 Sâmin (8. Fasl) 60. Maddesinde;

“Erbâb-1 cünhadan mahallince te'dîbleri lâzım gelen eşhâsın isim ve şöhret ve keyfiyet-i cünha-1 sâbiteleri bend bend yazılarak ol bâbda kanûnnâmeye tatbîkan tezekkür ve tensîb olunan suver-i cezâiyeleri her birerlerinin üzerlerine sürhle şerh virilerek beher mâh Bâb-1 Âlîye takdîm olunmak üzere tanzîm olunacak jurnali meclisce bi’l-temhîr takdîm olunacaktır,"22

şeklinde ifade edildiği üzere meclislere burada gördükleri ceza davalarında yer alan suçluların isimlerini, şöhretlerini, suçlarını bendler halinde yazarak her bir bendin üzerine yürürlükte olan ceza kanununa uygun olarak tayin edilen cezası da yazılarak her ay bir jurnal hazırlamaları talimatı verilmiştir. Nitekim Cumhurbaşkanlığı Osmanlı Arşivi’nde yer alan belgelere bakıldığında 1849 (h. 1265) tarihinden itibaren taşradan gönderilen yüzlerce jurnale rastlamak mümkündür. ${ }^{23}$

Taşradan gelen jurnallerin yapısı şu şekildedir:

1- Jurnalin başında davaların görüldüğü meclisin ismi ve jurnalin içeriğginde yer alan davaların tarihlerini içine alan genel bir tarih aralığını bildiren yazı yer almaktadır.

2- Mezkûr meclisin bulunduğu eyalet veya bağlı kazalarda işlenen suçlar ve bu suçları işleyen kimselerin isimleri siyah yazı ile bendler halinde yazılmaktadır.

3- Her bir bendin üzerinde suçlu hakkında verilen hüküm kırmızı ve eğik yazı ile yazilmaktadır.

4- Jurnalin sonunda üst makama hitaben jurnalin sunulduğunu belirten bir yazı, jurnalin hazırlandığ 1 tarih ve meclis üyelerinin mühürleri yer almaktadır. ${ }^{24}$

Örneğin; 21 Muharrem 1266 tarihinde Edirne Meclisi'nden gönderilen bir ceza jurnali şöyledir:

Jurnalin üst yazısl: "İşbu altmış beş senesi ağustosunun on beşinci gününden eylül ğâyesine kadar bir buçuk mâh zarfında Edirne Eyâleti'nde zuhûr idüb eyâlet-i mezkûre meclisinde murâfaa ve muhakemeleri bi'r-ru'ye Kanûn-1 Ceza hükmüne tevfikan cezâları icrâ olunmak üzere mazbataları tanzim olunmuş olan erbâb-ı cünha jurnâlidir.” (Siyah yazı ile yazılmıştır.)

22 Cumhurbaşkanlığı Osmanlı Arşivi (BOA), Bâb-ı Âsâfî- Divân-ı Hümâyûn Sicilleri Nizâmât Defterleri (A.(DVNSNZAM.d), No.00044, 73.

23 Örneğin; Edirne Eyâlet Meclisinden gönderilen jurnal için bakınız: Cumhurbaşkanlığı Osmanlı Arşivi (BOA), Sadâret-Mektubî Kalemi Umum Vilâyât (A.\}MKT.UM), No. 2, Gömlek No. 61, 2-4; Kürdistan Meclis-i Kebîri'nden gönderilen jurnal için bakınız: Cumhurbaşkanlığı Osmanlı Arşivi (BOA), Meclis-i Vâlâ (MVL), No. 203, Gömlek No. 79, 3-6; Tırhala Meclisi'nden gönderilen jurnal için bakınız: Cumhurbaşkanlığı Osmanlı Arşivi (BOA), Meclis-i Vâlâ (MVL), No. 207, Gömlek No. 60, 1; Selanik Meclisi’nden gönderilen jurnal için bakınız: Cumhurbaşkanlığı Osmanlı Arşivi (BOA), Meclis-i Vâlâ (MVL), No. 207, Gömlek No. 77, 1.

24 Edirne Meclisi'nden gönderilen bir jurnal olup, mezkur belge için bakınız: Cumhurbaşkanlığı Osmanlı Arşivi (BOA), Meclis-i Vâlâ (MVL), No. 2, Gömlek No. 61, 2-3. Bazı jurnallerde istenilen şekilde düzene uyulmadığ1 da gözlenir. Örneğin; Tırhala Meclisi'nden gönderilen jurnalde işlenen suçlar için tayin edilen cezaları bendin devamında siyah yazı ile yazılmıştır. Mezkûr jurnal belgesi için bakınız: Cumhurbaşkanlığı Osmanlı Arşivi (BOA), Meclis-i Vâlâ (MVL), No. 207, Gömlek No. 60, 1; Yenipazar Meclisi'nde gönderilen jurnalde de yine bu

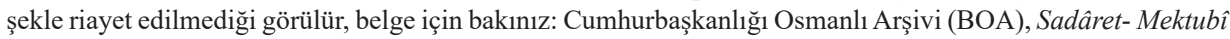
Kalemi Umum Vilâyât (A.\}MKT.UM), No. 242, Gömlek: 42. 
Bend halinde yazllan suç ve suçlunun ismi: "Keşân Kazası mütemekkinlerinden terzi Nikola ile bakkal Dimitri'nin yedi mâh mukaddem dükkanlarından leylen sirkat olunan beş bin kadar kuruşluk mal ve eşyanın sârikleri el-yevm Keşân'da bulunan kasab Yani ve ... olduğunu bi'l-ihbâr-1 celîle murâfaaları icrâ ve ihkâk-1 hak olunması hususu istidâ olunmuş olmağla merkûmlar kazâ-i mezbûr tarafından celb ve istintâk olunduklarında madde-i sirkati eğerçi inkâra tasaddî eylemiş ise de beyân ve ifâdelerinde tezat vukûyla zan ve şübühât-1 kaviyye hâsıl olarak merkûmların sâbıkaları dahi haber virilmişdir." (Siyah yazı ile yazılmıştır.)

Davanın hükmü: "Mâl-1 mesrûku haber virmek ihâfesiyle merkûmların haklarında vâki' olunan zan ve şüphe zâil oluncaya kadar bir müddetcek habsleri tensîb ve mazbatası virilmişdir." (Bendin üst kısmında, eğik ve kırmızı yazı ile yazılmıştır.)

Jurnalin sonunda yer alan yazı: "Deâvi-i resmiyye mahkemeye havale olunmakta olduğu halde meclisce ru'yet olunan bazı ahz ü i’tâ misillü deâvînin murâfaaları icrâ olunub ber vech-i ta'lîmât-1 seniyye i'lâm ve mazbataları tanzîm olunan mevâddan mâ adâ ashâb-1 cünhadan olmak üzere müddet-i mezkûrede meclisce bi'r-ru'ye iktizâ iden mazbataları virilmiş olan işbu on beş mevâddın dahi îcâb-ı hâli ve iktizâ-yı mevkıa tatbîken meclisce tensîb olunan cezâları sürhle bâlâlarına tahrîr ve işâret olunmağla zîri dahi bu vechle şerh ve temhîr ve hâkipây-i âliye takdim kılınmışdır ol-bâbda emr ü fermân hazret-i veliyyü'l-emrindir.” (22 Muharrem 1266- Meclis üyelerinin mühürleri vardır.) ${ }^{25}$ (Jurnal için bakınız: Ek-2)

Taşradan gönderilen ceza jurnallerinin hemen hepsinde yukarıda zikredilen şekilsel özelliklere uyulduğu gözlemlenmiştir.

\section{Taşrada Bir Davanın Karara Bağlanma Süreci ve Ceza Jurnallerinin İşlevi}

Tanzimat'ın ilanı sonrası değişen ceza yargılama sistemi ile taşrada vuku bulan bazı suçlara ${ }^{26}$ ait davaların, görülmeye başlanmasından haklarında hükmün sabit olmasına kadar geçen süreçte birtakım aşamalardan geçtiğine tanık olunmuştur. Eyaletlerdeki Meclis-i Kebirler ile Dersaadet’teki Meclis-i Vâlâ, davanın karara bağlanmasında etkili iki organ haline gelmiştir. Taşrada bulunan Meclis-i Kebirlerde dava ile ilgili gerekli tetkikat ve istintaklar yapılıp dava şer'î usule göre görülür ve karara bağlanırdı. Bunun sonucunda hazırlanan i'lâm ve meclis mazbatası eyalet valisinin olayı özetleyen tahrîri ile bir üst derecedeki Meclis-i Vâlâ'ya gönderilirdi. Meclis-i Vâlâ ise dava evraklarını öncelikle Fetvahaneye gönderir, Fetvahane Eyalet Meclisinde görülen davanın şer'î usule uygun olarak görülüp görülmediğini, dava i'lâmında şer'an bir eksiklik olup olmadığını kontrol eder, buna dair bir ilam yazar ve Meclis-i Vâlâ'ya sunard1. Meclis-i Vâlâ Fetvahanenin verdiği i'lâmı, taşradan gelen i'lâm ve mazbataları inceleyerek kararı onaylar veya bazen yeni tetkikler ve istintaklar yapılmasını ister ve kararı o zamana kadar erteleyebilir ya da verilen kararı değiştirerek farklı bir karar verebilirdi. ${ }^{27}$

25 Cumhurbaşkanlığı Osmanlı Arşivi (BOA), Sadâret-Mektubî Kalemi Umum Vilâyât (A.łMKT.UM), No. 2, Gömlek No. 61, 2-4.

26 Bununla, 1840 ve 1851 tarihli Ceza Kanunlarında belirtilen suçlar kastedilmektedir.

27 Ayrıntılı bilgi için bakınız: Kübra Nugay, XIX. Yüzyll Ortak Ceza Hukuku Dilinin Oluşumu: Osmanlı'da Ta 'zîrin Kalkması, 79-80, 95-96. 
Tanzimat sonrası düzenlenen bu yeni yargılama sisteminde dikkat çeken özelliklerin başında, davanın görülmeye başlanmasından hükme bağlanmasına kadar geçen sürecin, taşradan Dersaadet'e uzanan hiyerarşik basamaklar şekilde yapılandırılması gelir. ${ }^{28}$ Gerek Dersaadet'te gerekse taşrada işlenen suçların davalarının görülmesinde ve karara bağlanmasında, bu şekilde hiyerarşik aşamaların inşa edilmesinin sebebinin, merkezin ceza hukukunu kullanarak taşra üzerindeki kontrol mekanizmasını kuvvetlendirmek istemesi olduğu yorumu yapılabilir. Nitekim bu konuda önemli bir çalışmaya sahip olan Omri Paz, Osmanlı'nın Tanzimat'ın erken döneminde böyle bir ceza yargılama sistemi geliştirmesinde dahili etkenlerin ön planda olduğunu, taşrayı kaybetmemek adına Tanzimat sonrası merkezileşen ve müdahaleci bir devlet politikası izlediğini, bunun gereği olarak da yeni bir ceza yargılama sistemine ve ceza kanununa ihtiyaç duyduğunu söyler. ${ }^{29}$ Bu dönemde, Osmanlı'ya bağlı hidivlik statüsü verilen Mısır'ın, kendi içerisinde Osmanlı' dan farklı ancak benzer yeni ceza yargılama sistemi inşa etmesinin arkasında yatan sebepleri Rudolph Peters şu şekilde açıklamıştır: Yerel idarî meclislerin kurulması ve bunlara suçluları muhakeme yetkisinin verilmesiyle yerel yöneticilerin keyfî ve sınırsız güçleri kısıtlanmış olacaktı, ayrıca bu yetkinin sınırı ceza kanunları ile belirgin hale getirilecekti. Aldıkları kararlar yönetim merkezine gönderilerek onaylanması istenecek, böylece merkez Kahire'nin, çevre şehirler üzerindeki kontrol gücü artırılmış olacaktı. ${ }^{30}$ Osmanlı'nın da Mısır' dakine benzer nedenlerle taşranın en küçük birimlerine dahi meclisler kurarak özellikle XVIII. yüzyıl taşrası, âyan ve voyvodaların artan şekilde halka zulümlerine, merkezden gönderilen emirlere karşı hareketlerine, kendi menfaatleri söz konusu olduğunda gerekirse eşkıya ile iş birliği yaptıklarına şahit olunmuştur. ${ }^{31} \mathrm{Bu}$ durum merkezin taşra üzerindeki hakimiyetinin azalmasına, taşrada önemli bir olay olduğunda müdahale edememesine ve yerel güçlerin kontrolü ele geçirmelerine neden olmuştur. 1808 tarihli Sened-i İttifâk bunun en açık örneğidir. Diğer taraftan milliyetçilik akımları sonrası 1812 tarihinde Yunan İsyanı ile Osmanlı'dan ilk kopuşun yaşanması, bu konuda devleti yeni tedbirler almaya sevk etmiştir. $\mathrm{Bu}$ anlamda taşrada kurulan meclislerle taşrayı kontrol altına almak, yerel güçlerin de dahil edildiği bu meclislere ceza davası görme yetkisi verilerek onları devlet sistemine dahil etmek amaçlanmıştır. Bir ceza davasının yerel mecliste görülmesinden merkezde hükme bağlanmasına kadar izlenen çeşitli hiyerarşik aşamalar tam olarak merkezin taşrayı ve yerel güçleri kontrol etme, kontrol altında tutma isteğinin tezahürüdür, yorumu yapılabilir.

Ceza kanunları ve yargılama sisteminde görülen bu önemli iki değişimin pratikte beklendiği şekilde uygulanmasını ve bu yeni sistemin aksamadan işlerliğini sağlamak adına çeşitli önlemler alındığı görülür. Ceza jurnallerini alınan bu önlemler kapsamında değerlendirmek mümkündür.

28 Bu konuda "hiyerarşik" ifadesinin ilk kullanımı Omri Paz’a aittir.

29 Omri Paz, "Documenting Justice: New Recording Practices and the Establishment of an Activist Criminal Court System in the Ottoman Provinces (1840-late 1860s)", Islamic Law and Society 21 (2014), 84-87.

30 Rudolph Peters, "Administrators and Magistrates: The Development of a Secular Judiciary in Egypt, 1842-1871", Die Welt des Islams New Series 39/ 3 (1999), 392-393.

31 Kal'a-bend defterlerinde bunlarla ilgili çok sayıda örneğe rastlamak mümkündür. 
Özellikle 1849 yılında Eyâlet Meclisleri Nizâmnâmesi 60. Madde ile taşradaki meclislerden her ay hazırlanarak Meclis-i Vâlâ'ya göndermeleri istenen ceza jurnallerinin üst kısmında ve bazılarının son kısmında yer alan “...eyâlet-i mezkûre meclisinde murâfaa ve muhakemeleri bi'r-ru'ye Kanûn-1 Cezâ hükmüne tevfîkan cezâları icrâ olunmak üzere mazbataları tanzim olunmuş olan erbâb-1 cünha jurnâlidir" şeklindeki ifadeden de anlaşılacağı üzere bu jurnaller, içeriğinde bendler halinde yazılan suçlar için belirlenen cezaların ceza kanununa uygun olarak tayin edilmesini sağlamak ve meclisler tarafından uygulandığını göstermek amacıyla hazırlanmaktadır. Nitekim hazırlanan bu jurnaller ve meclis mazbatası, eyâlet valisinin veya sancak kaymakamının tahriri ile birlikte Sadarete sunulmak üzere posta yoluyla Meclis-i Vâlâ'ya gönderilmekte ve burada jurnalde yazılı olan hükümlerin ceza kanununa uygun olarak tayin edilip edilmediği incelenerek her bir bend hakkında açıklamanın yapıldığı bir mazbata (bazen ise bir şukka) hazırlanır ve aynı yolla ilgili yerel meclise gönderilirdi. Böylece Meclis-i Vâlâ tarafindan ceza kanununa uygun olarak ceza tayin edilen ve edilmeyen bendler belirlenerek uygun olmayan bendler için verilmesi gereken hüküm belirtilirdi. ${ }^{32}$ (Örnek bir jurnal, meclis mazbatası, vali tahriri ve Meclis-i Vâlâ'dan gönderilen mazbata veya şukka için bakınız: Ek3, Ek-4, Ek-5, Ek-6)

Yeni ceza yargılama sistemi içerisinde taşrada bir mecliste görülen davada yeni yürürlüğe konulan ceza kanunun uygulanmasını sağlamak veya nasıl uygulandığını kontrol etmek amacıyla devreye konulan jurnallerden beklenen verimin alındığını söyleyebiliriz. Zira ceza jurnallerinin taşradaki eyaletlerde uygulanmaya başlandığı ilk dönemlerde Meclis-i Vâlâ’ya gönderilen jurnallerin geri iade edildiği görülür. Bunun nedeni işlenen suçlar hakkında verilen cezaların kanunnameye uygun hüküm verildiği söylense de tam olarak kanunnameye uygun cezaların tayin edilmemesi, kanunnamenin uygulanmamasıdır. Örneğin 1851 (h. 1267) senesinde Edirne Meclisi'nden gönderilen ceza jurnali Meclis-i Vâlâ tarafından incelenerek jurnaldeki birçok suç hakkında tayin edilen cezanın kanuna uygun olmadığ 1 tespit edilmiştir. ${ }^{33}$ Ancak zaman içerisinde ceza kanununa uygun ceza tayin edilmeye başlandığ Vâlâ tarafından gönderilen mazbatada kanuna uygun olmayan cezaların ifade edildiği bend

32 Cumhurbaşkanlığı Osmanlı Arşivi (BOA), Sadâret-Mektûbî Kalemi Umum Vilâyât (A.\}MKT.UM), No. 00236, Gömlek No. 00026, 001, 001.

33 "Edirne Meclisinde ru’yet ve icrâ olunan bazı mevâd-ı hafîfe-i kanûniyeye şâmil usûl-i vechle tevârüd idülüb Meclis-i Vâlâya i’tâ buyurulan jurnallerden geçen altmış yedi senesi zilhiccesi selhinde muharrer ashâb-1 cünhadan bazılarının tahdîd olunan cezâları yolunda ise de ekserîsinin hükmü usûl-i kanûna tevâfuk itmediğinden iktizâları bend-i bâlâlarına siyâh mürekkeb ile işaret kılınmış olduğundan jurnal-i mezkûrun emirnâme-i sâmi-i vekâletpenâhileriyle mahalline irsâli Meclis-i Vâlâda tezkere kılınmış ise de ol-bâbda tevcîyle emr ü irâde-i seniyye-i vekâletpenâhileri müteallik buyurulmak ise ona göre icrâ-yı îcâbı bâbında emr ü ferman hazret-i men lehu'l-emrindir.” 29 Safer 1268 (Meclis-i Ahkâm-1 Adliye Mührü) Cumhurbaşkanlığı Osmanlı Arşivi (BOA), Sadâret-Mektubî Kalemi Meclis-i Vâlâ Evrakı (A.\}MKT.MVL), No. 48, Gömlek No. 94. 
sayısında azalma olduğu görülmektedir. ${ }^{34}$

Süreç içerisinde ceza jurnalleri ile ilgili karşılaşılan birtakım sorunlar da olmuştur. Bunlardan en önemlisi jurnallerin zamanında gönderilmemesi ya da hiç gönderilmemesi sorunudur. Örneğin; Rumî takvime göre 1270 (m. 1854) senesinde Kastamonu Meclisi’nden Meclis-i Vâlâ'ya gönderilen jurnallerden birinde Ağustos ayı başından Teşrinievvel ayı sonuna kadar üç ay zarfında Kastamonu Sancağı'nda vuku bulan suçların ve cezalarının yazıldığı görülür, oysa 1849 yılında gönderilen talimatnamede bir aylık sürede işlenen suçların yazılması istenmiştir. ${ }^{35}$ Yine Rumî takvime göre 1271 (m. 1855) senesinde Rodos Meclisi'nden Meclis-i Vâlâ'ya gönderilen bir jurnalin Nisan ayı başından Eylül ayı sonuna kadar beş ay zarfında vuku bulan olayları içerdiği görülmüştür. ${ }^{36}$ Yani vuku bulan hadiseler, işlenen suçlara dair yürütülen muhakeme ve tayin edilen ceza hakkında Dersaadet'e geç bilgi verildiği görülür.

Ceza jurnalleri ile ilgili yaşanan sorunlardan bir diğeri Meclis-i Vâlâ'ya ulaşan mezkûr jurnallerde yer alan suçlar için tayin edilen cezaların dönemin mevcut ceza kanununa uygunluğunun Meclis-i Vâlâ tarafindan incelenmesinin ve hazırlanan bu mazbatanın yerel

34 "Yetmiş senesi mah-1 ağustos ibtidasından sene-i merkûme teşrinevveli ğayetine değin üç mah zarfında Kastamonu Sancağında vukû' bulub liva-yı mezkûr meclis-i kebîrinde muhakemeleri icrâ olunan bazı ashâb-1 cünhanın derece-i töhmet ve kabahatlarına göre haklarında tahdîd olunan müddet-i cezâlarını mübeyyin zîri mazbatalu gelen jurnal Meclis-i Vâlâya lede'l havâle içlerinden Çayırcık divâni ahalisinden Dolabcı oğlu Abdullah ile İhsangazi divandan Şaban oğlu Süleymanın kızlarının bikrini izâle itmiş olan Çâyır divanî ahalisinden Köresinin oğlu Mehmed ile Merkûze kazasına tabi Akkaya divanî sâkinlerinden vali Osman oğlu Mehmedin tahdîd olunan müddet-i cezaiyeleri töhmet vakıalarına cezâyı kâfi olamadığı gibi Topcu mahallesi sâkinlerinden Börekçi Ahmedin oğlu Satının ırzına tasallut iden Sofiler Mahallesinden Kalbak oğlu Hafız Mehmed ve Hüccac oğlu Mehmed Kâmil ve Yasin oğlu Mehmed ile Eztava kazasına tabi Şeyh Emrullah Divani ahalisinden Kadir oğlunun kızı Fatıma nam hatunu fil-i şeni' kasdıyla cebren dağa götürmüş olan Çolak kadı oğlu Osman ile Akbaş oğlu Mehmed ve Kız oğlu Mahmud nam şahıslar hakkında değnek darbı gibi tertib ve icra olunan cezalardan göründüğünden izâle-i bikr fezahata ictisâr iden merkumân Köresinin oğlu Mehmed ile Osman oğlu Mehmedin ber mûceb-i kanun-1 ceza mahbusiyetleri tarihinden itibaren birer sene ve kusurlarının dahi altışar mah müddetle vaz-1 pranga olunarak hitâm-1 müddetlerinde kavi kefiller alınup sebillerine tahliyesi ve bunlardan mâ adâ mücrimînîn te'dîb ve terbiyeleri ... bende olduğundan iktizâlarının icrâsı lâzım geleceği meclis-i mezkûrdan bâ mazbata ifâde olunmuş ve mezkûr jurnal leffen gönderilmiş olmağla ber minval-i muharrer iktizasının icrâsı husûsuna himmet buyurmaları siyakında şukka" (13 Cemaziyelahir 1271) Cumhurbaşkanlığı Osmanlı Arşivi (BOA), SadâretMektubî Kalemi Meclis-i Vâlâ Evrakı (A.\}MKT.MVL), No. 00071, Gömlek No. 00007, 001, 001; Başka bir mazbata ise şu şekildedir: "Kastamonu Eyaletinde 75 senesi teşrinievvelinin ibtidâsından kanunuevveli ğayetine değin vukû' bulan cünha ve kabahat ashâbının derece-i töhmetleriyle haklarında tahdîd ve icrâ kılınan cezâ ve muameleyi mutazammın vârid olan tahrirât saadetleriyle Kastamonu Meclisinin zîri mazbatalu yirmi sekiz bend bir kıt'a jurnali Meclis-i Vâlâya lede'l havâle jurnal-i mezkûrde muharrer icraatın cümlesi yolunda ve muvâfik-1 kanun olub fakat on yedinci bendinde muharrer ... eşhasın mücâzatları Kanûn-1 Cezânın 201. maddesine tatbîk kılınmış ise de bunlar hakkında emsaline tevfîken muamele olunmasının ve yirmi beşinci bendinde gösterilen noksan inzârının zabtı lazım geleceğinin ve mevâdd-1 sâirenin dahi ber mûceb-i istizan icrâ-yı iktizâlarının savb-1 saadetlerinden bildirilmesi meclis-i mezkûrden bâ mazbata ifade olunmuş ve zikr olunan jurnal leffen iade kılınmış olmağla ber minvâl-i muharrer iktizâlarının ifâsı husûslarına himmet eylemeleri lazım geleceği beyanına şukka" (5 Ramazan 1276) Cumhurbaşkanlığı Osmanlı Arşivi (BOA), Sadâret-Mektubî Kalemi Meclis-i Vâlâ Evrakı (A.\}MKT.MVL), No. 115, Gömlek No. 76.

35 Cumhurbaşkanlığı Osmanlı Arşivi (BOA), Sadâret-Mektubî Kalemi Meclis-i Vâlâ Evrakı (A.\}MKT.MVL), No. 00071, Gömlek No. 00007, 001, 001.

36 Cumhurbaşkanlığı Osmanlı Arşivi (BOA), Sadâret-Mektubî Kalemi Meclis-i Vâlâ Evrakı (A.\}MKT.MVL), No. 78, Gömlek No. 90. 
meclise gönderilmesinin zaman almasıdır. Bu durum, ceza davalarının hükme ulaşma süresinin uzaması anlamına gelmektedir. Örneğin 1271 senesi Nisan ayından Eylül ayına kadar Rodos Meclis-i Kebîri'nde görülen davalara dair hazırlanan jurnal Eylül ayı sonunda Meclis-i Vâlâ'ya gönderilmiş, Meclis-i Vâlâ tarafından incelenen jurnale yazılan mazbata ise yerel meclisin bağlı olduğu Cezâyir Vâlisi'ne 12 Eylül 1272 tarihinde ulaşmıştır. Yani jurnalde yer alan suçlar için tayin edilen cezaların gözden geçirilip ceza kanununa uygun ceza tayin edilip edilmediğinin kontrol edilmesi ve bunun yerel meclise bildirilmesi ancak bir yıl sonra mümkün olmuştur. Bu durum, taşrada meydana gelen bir vukuata merkezin müdahale etme imkânın halen zor olduğu ve işlenen suç karşısında verilen cezanın incelenerek onaylanmasının uzun zaman alması nedeniyle adaletin geç tecelli ettiği anlamına gelmektedir. Bu ise özellikle XIX. yüzyılda kendini daha belirgin şekilde gösteren Osmanlı'nın taşrayı elde tutma isteğinin ve merkezîleşme politikasının henüz beklenilen seviyede olmadığını göstermektedir. Esasen taşradan gönderilen jurnaller posta yoluyla gönderilmekteydi ve Osmanlı Devleti daha II. Mahmud döneminde merkezîleşme siyasetinin gereği olarak iletişim ve ulaşım vasıtalarının artırılmasına, posta teşkilatının kurulmasına önem veriyordu. İlk olarak 1 Kasım 1831 tarihinde yayınlanan devletin resmî gazetesi olan Takvîm-i Vekâyi ile tebaa üzerinde etkili olmayı, yönetenle yönetilen arasında hızlı iletişim imkanına sahip olmayı hedeflemiştir. ${ }^{37}$ Bundan bir sene sonra posta hizmetinin kurulması için teşebbüslere başlamış, ancak sekiz sene sonra 23 Ekim 1840 tarihinde Posta Nezareti kurulmuştu. Öncelikle merkezdeki teşkilat yapılandırılmış, daha sonra taşrada gerekli düzenlemeler yapılmış ve 1849 yılına kadar çalışmalar devam etmiştir, neredeyse tüm taşrada posta hizmeti verilir hale gelmiştir. ${ }^{38}$ Ancak 1854 yılında Basra Eyalet mustasarrıfı Muhammed Yasin'in Sadaretten gönderilen emirnameye cevaben Basra'ya halen posta hizmetinin ulaşmaması nedeniyle eyaletten gönderdikleri jurnallerin vaktinde Dersaadet'e ulaştıramadıklarını dile getirmesi, Osmanlı'nın posta teşkilatı kurulduktan uzun süre sonra dahi Basra gibi uzak eyaletlerle aralarında haberleşme konusunda halen sıkıntılar

37 Nesim Yazıc1, "Tanzimat Döneminde Osmanlı Haberleşme Kurumu”, 150. Yılında Tanzimat, haz: Hakkı Dursun Yıldız (Ankara: Türk Tarih Kurumu Yayınları, 1992), 142.

38 Nesim Yazıcı, “Tanzimat Döneminde Osmanlı Haberleşme Kurumu”, 146-161. 
yaşadığı anlamına gelmektedir. ${ }^{39}$

Taşradaki meclislerde görülen ceza davalarında ceza kanununun uygulanıp uygulanmadığını, dahası doğru uygulanıp uygulanmadığını takip etmeyi sağlayan ceza jurnallerinin, zamanla bu işlevinin yanında taşra ile Dersaadet arasında bir haberleşme zinciri görevini de üstlendiği hatta bu yönünün daha ön plana çıktığg görülür. Ancak yukarıda da bahsedildiği üzere süreç içerisinde bu jurnallerin geç gönderilmesi ya da hiç gönderilmemesi söz konusu olmaya başlamış, dolayısıyla taşra ile Dersaadet arasındaki bu haberleşme zincirinde kopukluklar oluşmuştur. Nitekim bu durum bir süre sonra artarak devam etmiş olsa gerekir ki; 1856 (h. 8 Şaban 1272) tarihinde Meclis-i Âlî-i Tanzimat’ta karar alınmış ve Padişahın irâde-i seniyyesi

39 'Ma'rûz-1 çâker-i kemîneleridir ki,

Vukûât-1 mahalliyenin beher hafta veyahud on beş günde bir def'a jurnal şeklinde olarak bend bend tahrîr ve üzerlerine muhâkemât-1 mukteziyelerin ne suretle rivayet ve tesviye olunduğu işâret ve tezbîr k1lınarak takdîm kılınması Meclis-i Âlî-i Tanzimât karârı ve irâde-i seniyye-i cenâb-1 tâcidarî iktizâ-yı âliyesinden bulunduğu beyân-1 vâlâsıyla îcâb-1 hâlin icrâsı husûsuna mübâderet ... irâdesini hâvî 8 Şaban 1272 tarihiyle karîn hâmeerâyı ta'zîm ve tekrîm olan emirnâme-i sâmi ... meal-i ulyâsı rehin-i îkân-1 çâkerânem olmuşdur bâbından müstağni olduğu vech üzere Basra Eyâletine şimdiye kadar posta tertîb ve teşkîl olunmamış olmasıly musâlaha-1 mühimme ve husûsât-1 mülkiyeye dâir Dersaadet'e takdîm kılınmakda olan ma'rûzât ve muharrerât-1 çâkerânem gâh sâî ve gâh yolcu ve bazen bi’t-tesâdüf İngiltere Devleti fehâmetinin olub Basra'dan Bağdat'a işlemekte olan ve ... vâsıtasıyla Bağdat'a ve Bağdat'tan posta ile Dersaadet'e takdîm kılınmakta olmasına mebnî husûsât-1 mezkûrenin ol vechle vakt ve zamânında arz ve işârına bil kadr muvakkat hâsıl olamamış ve mamafih tıbk irâde ve ferman buyurulduğu vechle bundan böyle elden geldiği mertebe îcâb-1 hâlin sürat icrâsına mübâderet kılınacağı derkâr bulunmuş olduğu ... âlî vekâletpenâhileri buyuruldukda ol bâbda ve herhâlde emr ü fermân hazret-i men lehü'l- emrindir." Cumhurbaşkanlığı Osmanlı Arşivi (BOA), Sadâret-Mektubî Kalemi Nezâret ve Devâir (A.\}MKT.UM), No. 239, Gömlek No. 15. 
ile Sadaretten eyalet valilerine ve sancak kaymakamlarına bir emirname ${ }^{40}$ gönderilmiştir. Buna göre gerektiğinde her hafta veya on beş günde, bir şey vaki olmazsa "vukuât-1 mülkiye ve cinâyât-1 cesîmeye dâir bir şey zuhûr itmedi" şeklinde bir ay zarfinda Sadarete haber verilmesi vali, mutasarrıf ve kaymakamlara emredilmiştir. Emirnamede taşrada meydana gelen önemli vukuatların ve suçların Dersaadet'e jurnaller halinde bildirilmesi için posta teşkilatı kurulduğunu ancak eyalet ve sancaklarda bu işle görevli olan memurların jurnalleri geç hazırlayıp gönderdiklerinden, hatta bazı meclislerin hiç göndermediğinden bahsetmektedir. Bu noktada ilgili memurların görevlerini yapmamaları halinde bundan mesul tutulacakları ifade edilmiştir. Bu emirnamenin gönderilmesi üzerine tüm eyalet valilerinden ve sancak kaymakamlarından emirnamenin gereğinin yapılacağına dair şukkaların gönderildiği görülür. ${ }^{41}$ (Örnek bir şukka

40 "Hamd olsun memâlik-i mahrûse-i hazret-i şâhânenin vüs'ati cihetiyle vukûatı dahi eksik olmayub şayân-1 dikkat olan vukûatın vakt ve zamanıyla bu tarafça bilinmesi lâzım gelerek halbuki sâye-i şevketvâye-i hazret-i şâhâneden tesrî’-i mühâberât zımnında posta usûlü dahi vaz' ve icrâ kılınmış olmasıyla bu vâsıta ile gerek mevâdd-1 mühimme ve gerek vukuat-1 cesîmenin derhâl bu tarafa işârı lâzimeden ve bu ise müstahdem-i me'mûriyet olan mevâddan iken ekserlerde bu maddelerde takayyüd olunmamasından dolayı hîn-i vukûatta işâr olunmayub sonralarda yazılmakta ve bazı mahallerden hiç iş'âr olunmayarak ekseriya cânib-i ecânibden mübâlağalıca ifâde ve rivâyet olunmakta ve adem-i ma'lûmât ve istitlât cihetiyle tekzîb ve tasdik ve bir madde hakkında olan teşebbüsâta dâir bunlara vuku'-1 sahîha üzere lâ yekau cevâb virilmeyüb mûcib-i hacâlet olmakda ve bunun üzerine sonra böyle şeylerin taşralarda derhâl yazılamamasının sebebleri dahi mesâlih-i vâkıanın iktizâsına göre ya muhakemesine veyahud tahkîkine mübâşeret ile ba'dehu yazılmak üzere ... ta'lîk olunmasından ve bir de dâhil-i eyâlet ve livada öyle bir hilâf-1 marzî şey vukû'u merkez hükümetin şayet adem-i dikkat ile müsâmahasına mahmûl olub da mes'uliyetini mûcib olduğu mütalaât-1 vâhiyeye sapılması ihtimâlinden neş’et itmesiyle bundan böyle umûr-1 mühimme-i mülkiyeve cinâyât-1 cesîmeye dâir vukuat zuhurunda tafsîlâtı ba'dehu yazılmak üzere ol emirde jurnal şeklinde olarak sathîce vukuat-1 mülkiye veyahud cinâyât-1 cesîmeden şöyle bir şey zuhûr itmişdir yollu yazılub meselâ katl maddesine dâir ise filan falancayı cerh veya katl eylemişdir veyahud şu yerde kat' olunmuşdur ve böyle bir husûs vukû' bulmuşdur deyu bend bend tahrîr ve üzerlerine dahi muhakemesine mübâşeret olunmuş ise muhakemesinin icrâsına başlanmışdır ve tahkîk olunacak husûs olduğu halde tahkîkine teşebbüs kılınmışdır veya ... tahkîkdir deyu işâret olunub vukûatın iktizâsına göre beher hafta veya üç beş günde ve bir şey vâki olmaz ise vukuât-1 mülkiye ve cinâyât-1 cesîmeye dâir bir şey zuhûr itmedi deyû nihâyet bir ay zarfında bu tarafa işârı zımnında iktizâ iden mahaller vülât-ı a'zâm ve mutasarrifîn-i kirâm ile liva kaymakamlarına tahrîrât-1 sâmiye tastîri ve tafsilât-1 icrâiyesi ba'dehu yazılmak üzere ol emirde bâlâda gösterilen usûle tatbîken maddesinin sathîce olarak evkât-1 mahdûdesinde Dersaadet'e bildirilmeyüb de sonra ahar tarafdan işidilür ise ol mahal me'mûrinin mes'ûl ve muateb olması lâzım geleceğinden burasının dahi tastîr olunacak tahrîrât-1 sâmiyeye derç ve ilavesi ve mevâd ve husûsât-1 vâkıanın sür'atle tesvîyesi iktizâ-yı halden bulunduğundan bu tarafça bir ay evvel kesb-i ma'lumât olmak ve iktizâsına bakılmak üzere dâhil kılınmada üç beş efendiden mürekkeb jurnal olması nâmıyla bir oda yapılarak taşralardan gelecek jurnallerin orada kaydedilmesi ve bunlardan pek mühim ve müsta'cil olanların hemân birer suretlerinin yazdırılarak kayddan evvel müteallik olduğu mahalle virdirilmesi ve sonra karâr icrâiyete dâir usûlü üzere Meclis-i Vâlâ’ya gelecek tahrîrât-1 resmiye üzerine işbu kuyûdun tashîh olunması suretinin icrâsı Meclis-i Âlî-i Tanzimatdan tezkere ve tensîb olunarak müteallik buyuruldusu irâde-i seniye mûcebince keyfiyet bâ tahrîrât-1 sâmi lâzım gelenlere bildirilmiş olmağla ber manzûr-1 irâde-i seniye işbu jurnal odasının teşkîliyle teferruatının icrâsına himmet olunmak üzere işbu ilm ü haber terkîm ve imlâ ve dâhiliye kitâbeti tarafına i’tâ olundu" (27.8.1272) Cumhurbaşkanlığı Osmanlı Arşivi (BOA), Sadâret-Mektubî Kalemi Nezâret ve Devâir (A.\}MKT.NZD). No. 184, Gömlek No. 19.

41 Çeşitli eyaletlerden ve sancaklardan gönderilen şukkalara dair belgeler için bakınız: Cumhurbaşkanlığı Osmanlı Arşivi (BOA), Meclis-i Vâlâ (MVL), No. 218, Gömlek No.64; Cumhurbaşkanlığı Osmanlı Arşivi (BOA), Meclis- $i$ Vâlâ (MVL), No. 218, Gömlek No.31; Cumhurbaşkanlığı Osmanlı Arşivi (BOA), Meclis-i Vâlâ (MVL), No. 187, Gömlek No. 68; Cumhurbaşkanlığı Osmanlı Arşivi (BOA), Meclis-i Vâlâ (MVL), No. 218, Gömlek No. 68; Cumhurbaşkanlığı Osmanlı Arşivi (BOA), Meclis-i Vâlâ (MVL), No. 218, Gömlek No. 94; Cumhurbaşkanlığı Osmanlı Arşivi (BOA), Meclis-i Vâlâ (MVL), No. 237, Gömlek No. 69; 
için bakınız: Ek-7). Nitekim 1856 (1272) tarihindeki bu emirnameden sonra eyaletlerden ve sancaklardan düzenli şekilde jurnallerin gönderildiğini görmek mümkündür. Yine emirnamede belirtildiği üzere jurnal takdimi için kayda değer bir suç işlenmediği durumlarda böyle suçların zuhur etmediğini haber veren bir yazının gönderilmesi istenmişti. Emirnamedeki bu emre uygun olarak bazı meclislerden Sadarete bu içerikte yazıların gönderildiği görülür. ${ }^{42}$ Eyaletlere gönderilen bu emirnamelerde ayrıca eyalet müşirlerden, mülhak liva kaymakamlarına ve kaza müdürlerine, bulundukları sancaklarda meydana gelen vukuat ve suçlar hakkında jurnaller hazırlayarak çeşitli tarihlerde Sadarete göndermeleri gerektiğinin haber verilmesi istenmiştir. ${ }^{43}$ Böylece taşradaki en küçük idarî birimden doğrudan merkeze kadar uzanan bir haber ağı geliştirilerek bu birimler üzerinde devlet, tam bir hakimiyet kurmak ve en küçük suçu ve buna verilen cezayı bile takip ederek hem asayişi hem adaleti temin etmek, ayrıca isyana teşvik edici en küçük hareketlenmeyi dahi takip ederek, bunların önüne geçmek istemiştir. Ayrıca mezkûr emirnamede zikredilen bir diğer önemli husus, taşradan gelen ceza jurnalleri için Dahiliye Kalemine bağlı bir jurnal odası oluşturularak burada görev yapmak üzere üç neferin tayin edilmesi kararının Meclis-i Âlî-i Tanzîmat tarafından alınmasıdır. Böylece özellikle acil olan jurnaller evraklara kayıttan önce cevaplandırılarak ilgili mahalle gönderilmesi mümkün hale gelecekti.

\section{Sonuç}

1839 yılında Gülhane Hatt-1 Hümâyûnu'nun ilanından sonra Osmanlı Devleti, ceza hukuku alanında önemli değişimlere sahne olmuştur. Bunları, kanunlaştırma ve yeni yargılama teşkilatı şeklinde iki ana başlıkta ifade etmek mümkündür. Bu önemli değişim süreci birçok yeni yapı, görev ve uygulamanın oluşumunu da beraberinde getirmiştir. Bu yeni uygulamalardan biri de ceza jurnalleridir. Esasen bendler halinde yazılmış bir haberleşme usulü olan jurnaller, Tanzimat öncesi klasik dönemde de görülmekle birlikte ceza jurnalleri ilk defa Tanzimat'ın ilanı sonrasında uygulanmaya başlanmıştır. Özellikle taşradaki meclislerde 1849 (h. 1265) tarihinden sonra hazırlanarak Dersaadet'e gönderilen bu jurnallerin, ceza hukukunun geçirdiği değişim süreci içerisindeki işlevini yeni vaz’ edilen ceza kanunlarının (1840, 1851 ve 1858) işlenen suçlara tatbik edilip edilmediğini izlemek olarak görmekteyiz. Zaman zaman uygulamada çeşitli sebeplerden dolayı aksamalar yaşansa da ceza jurnallerinden istenilen faydanın elde edildiği, ceza kanunlarının taşrada uygulandığı görülür. Süreç içerisinde ceza jurnallerinin önemli bir fonksiyonu daha ortaya çıkmıştır: Dersaadet, hazırlanan bu jurnaller vasıtasıyla taşradaki eyalet ve sancaklarda vuku bulan önemli olaylardan ve işlenen her türlü suçtan haberdar olmaktadır.

42 Cumhurbaşkanlığı Osmanlı Arşivi (BOA), Sadâret-Mektubî Kalemi Nezâret ve Devâir (A.\}MKT.UM), No.248, Gömlek No.90.

43 Cumhurbaşkanlığı Osmanlı Arşivi (BOA), Sadâret-Mektûbî Kalemi Umum Vilâyât (A.\}MKT.UM), No. 00242, Gömlek No. 00042, 001, 001; Cumhurbaşkanlığı Osmanlı Arşivi (BOA), Sadâret-Mektûbî Kalemi Umum Vilâyât

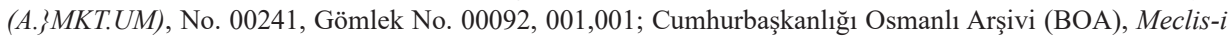
Vâlâ-Meclis-i Vâlâ Evrakı (MVL), No. 00224, Gömlek No. 00092, 001, 001. 
Taşrada kurulan meclislerde yerel önde gelenlerin görevlendirilmesi ve bu meclislere çeşitli suçlara dair davaları görme yetkisinin verilmesi sayesinde yerel güçlerin bağımsız hareket etmeleri engellenerek Dersaadet kontrolünde devlete hizmet etmeleri sağlanmış, bu meclislere verilen ceza davalarını görme yetkisi ile de özellikle ceza davalarında kayırılmaların önüne geçerek taşrada asayişi sağlamak istenmiştir. Bu noktada ceza jurnalleri taşranın en uzak biriminden Dersaadet'e uzanan bir haberleşme zinciri olup, bu jurnallerin özellikle ceza hukuku alanında hazırlanmasına önem verilmesi, devletin XIX. yüzyılda öne çıkan merkezileşme siyasetinde ceza hukuku faktöründen de faydalanmak istediği şeklinde yorumlanabilir. $\mathrm{Bu}$ çalışmada, Tanzimat'ın ilanı sonrası ceza jurnallerinin uygulandığı dönemin ceza kurumları, yapıları, devrede olan ceza kanunları ile olan ilişkisi de ortaya konarak dönemin değişen ceza hukuku yapısı farklı bir perspektiften anlaşılmaya çalışılmıştır.

Hakem Değerlendirmesi: Dış bağımsız.

Çıkar Çatışması: Yazar çıkar çatışması bildirmemiştir.

Finansal Destek: Yazar bu çalışma için finansal destek almadığını beyan etmiştir.

Peer-review: Externally peer-reviewed.

Conflict of Interest: The author has no conflict of interest to declare.

Grant Support: The author declared that this study has received no financial support.

\section{Kaynakça/References}

BOA, Cumhurbaşkanlığı Osmanlı Arşivi. Topkapı Sarayı Müze Arşivi (TS.MA.e), No. 700, Gömlek No. 19.

BOA, Cumhurbaşkanlığı Osmanlı Arşivi. Hatt-ı Hümayûnu (HAT), No. 394, Gömlek No. 20829.

BOA, Cumhurbaşkanlığı Osmanlı Arşivi. Hatt-ı Hümayûnu (HAT), No. 1268, Gömlek No. 49090.

BOA, Cumhurbaşkanlığı Osmanlı Arșivi. Cevdet-Maliye (C..ML..), No.375, Gömlek No. 15435.

BOA, Cumhurbaşkanlığı Osmanlı Arşivi. Sadâret-Mektûbî Evrakı (A.\}MKT.), No. 42, Gömlek No. 52, 2.

BOA, Cumhurbaşkanlığı Osmanlı Arşivi. Cevdet-Zabtiye (C..ZB..), No: 72, Gömlek No: 3586, 1.

BOA, Cumhurbaşkanlığı Osmanlı Arşivi. Bâb-ı Âsâfí- Divân-ı Hümâyûn Sicilleri Nizâmât Defterleri (A.(DVNSNZAM.d), No. 00044, 56-75.

BOA, Cumhurbaşkanlığı Osmanlı Arşivi. Sadâret- Mektubî Kalemi Umum Vilâyât (A.\}MKT.UM), No. 2, Gömlek No. 61, 2-4.

BOA, Cumhurbaşkanlığı Osmanlı Arşivi. Meclis-i Vâlâ (MVL), No. 203, Gömlek No. 79, 3-6.

BOA, Cumhurbaşkanlığı Osmanlı Arşivi. Meclis-i Vâlâ (MVL), No. 207, Gömlek No. 60, 1.

BOA, Cumhurbaşkanlığı Osmanlı Arşivi. Meclis-i Vâlâ (MVL), No. 207, Gömlek No. 77, 1.

BOA, Cumhurbaşkanlığı Osmanlı Arşivi. Meclis-i Vâlâ (MVL), No. 2, Gömlek No. 61, 2-3.

BOA, Cumhurbaşkanlığı Osmanlı Arşivi. Meclis-i Vâlâ (MVL), No. 207, Gömlek No. 60, 1.

BOA, Cumhurbaşkanlığı Osmanlı Arşivi. Sadâret- Mektubî Kalemi Umum Vilâyât (A.\}MKT.UM), No. 242, Gömlek: 42.

BOA, Cumhurbaşkanlığı Osmanlı Arşivi. Sadâret- Mektubî Kalemi Umum Vilâyât (A.\}MKT.UM), No. 2, Gömlek No. 61, 2-4. 
BOA, Cumhurbaşkanlığı Osmanlı Arşivi. Sadâret-Mektûbî Kalemi Umum Vilâyât (A.\}MKT.UM), No. 00236, Gömlek No. 00026, $001,001$.

BOA, Cumhurbaşkanlığı Osmanlı Arşivi. Sadâret-Mektubî Kalemi Meclis-i Vâlâ Evrakı (A.\}MKT.MVL), No. 48, Gömlek No. 94.

BOA, Cumhurbaşkanlığı Osmanlı Arşivi. Sadâret-Mektubî Kalemi Meclis-i Vâlâ Evrakı (A.\}MKT.MVL), No. 00071, Gömlek No. 00007, 001.

BOA, Cumhurbaşkanlığı Osmanlı Arşivi. Sadâret-Mektubî Kalemi Meclis-i Vâlâ Evrakı (A.\}MKT.MVL), No. 115, Gömlek No. 76.

BOA, Cumhurbaşkanlığg Osmanlı Arşivi. Sadâret-Mektubî Kalemi Meclis-i Vâlâ Evrakı (A.\}MKT.MVL), No. 78, Gömlek No. 90.

BOA, Cumhurbaşkanlığı Osmanlı Arşivi. Sadâret-Mektubî Kalemi Nezâret ve Devâir (A.\}MKT.UM), No.239, Gömlek No. 15.

BOA, Cumhurbaşkanlığı Osmanlı Arşivi. Sadâret-Mektubî Kalemi Nezâret ve Devâir (A.\}MKT.NZD). No. 184, Gömlek No. 19.

BOA, Cumhurbaşkanlığı Osmanlı Arşivi. Meclis-i Vâlâ (MVL), No. 218, Gömlek No. 64.

BOA, Cumhurbaşkanlığı Osmanlı Arşivi. Meclis-i Vâlâ (MVL), No. 218, Gömlek No. 31.

BOA, Cumhurbaşkanlığı Osmanlı Arşivi. Meclis-i Vâlâ (MVL), No. 187, Gömlek No. 68.

BOA, Cumhurbaşkanlığı Osmanlı Arşivi. Meclis-i Vâlâ (MVL), No. 218, Gömlek No. 68.

BOA, Cumhurbaşkanlığı Osmanlı Arşivi. Meclis-i Vâlâ (MVL), No. 218, Gömlek No. 94.

BOA, Cumhurbaşkanlığı Osmanlı Arşivi. Meclis-i Vâlâ (MVL), No. 237, Gömlek No. 69.

BOA, Cumhurbaşkanlığı Osmanlı Arşivi. Sadâret-Mektubî Kalemi Nezâret ve Devâir (A.\}MKT.UM), No. 248, Gömlek No. 90.

BOA, Cumhurbaşkanlığı Osmanlı Arşivi. Sadâret-Mektûbî Kalemi Umum Vilâyât (A.\}MKT.UM), No. 00242, Gömlek No. 00042, 001, 001.

BOA, Cumhurbaşkanlığı Osmanlı Arşivi. Sadâret-Mektûbî Kalemi Umum Vilâyât (A.\}MKT.UM), No. 00241, Gömlek No. 00092, 001,001.

BOA, Cumhurbaşkanlığı Osmanlı Arşivi. Meclis-i Vâlâ- Meclis-i Vâlâ Evrakı (MVL), No. 00224, Gömlek No. 00092, 001, 001.

Beyhan, Mehmet Ali. “II. Abdülhamid Döneminde Hafiye Teşkilatı ve Jurnaller”. Türkler. Ankara: Yeni Türkiye Yayınlar, 2002.

Bingöl, Sedat. Tanzimat Devrinde Osmanlıda Yargı Reformu: Nizamiye Mahkemelerinin Kuruluşu ve Işleyişi 1840-1876. Eskişehir: Anadolu Üniversitesi Edebiyat Fakültesi, 2004.

Ceza Kanunnâme-i Hümâyûnu. İstanbul: Süleymaniye Yazma Eserler Kütüphanesi, Esad Efendi, 1877.

Çadırcı, Musa. Tanzimat Sürecinde Türkiye Ülke Yönetimi. İstanbul: İmge Yayınevi, 2017.

Demiroğlu, Faiz. Abdülhamid'e Verilen Jurnaller (50 Yıldır Neşredilmeyen Vesikalar). İstanbul: Tarih Kütüphanesi, 1955.

Düstûr I. Tertîb. Dersaadet, Matbaa-i Âmire, 1282.

Engelhardt, Edouard-Philippe. Tanzimat ve Türkiye. trc: Ali Reşad. İstanbul: Kaknüs Yayınları, 1999.

Ergin, Osman Nuri. Mecelle-i Umur-ı Belediye: Tarih-i Teşkilat-ı Belediye. İstanbul: Matbaa-i Osmaniye, 1922. 
Heyd, Uriel. "Eski Osmanlı Ceza Hukukunda Kanun ve Şeriat”. Türk Hukuk ve Kültür Tarihi Üzerine. trc. S. Eroğlu. Ankara: Ankara Okulu, 2014.

İrtem, Süleyman Kani. Abdülhamid Devrinde Hafiyelikve Sansür. Haz. Osman Selim Kocahanoğlu. İstanbul: Temel Yayınları, 1999.

Kastamonu jurnal defteri (1254-1255/1838-1839): Metin ve Tipklbasım. haz. Abdulkerim Abdulkadiroğlu, İ. Hakkı Aksoyak, Necip Fazil Duru. Ankara: Başbakanlık Devlet Arşivleri Genel Müdürlüğü, 1998.

Kırlı, Cengiz. "Kahvehaneler ve Hafiyeler: 19. Yüzyıl Ortalarında Osmanlı'da Sosyal Kontrol”. Toplum ve Bilim 83 (1999/2000), 58-79.

Kırl1, Cengiz. Sultan ve Kaтиoyu, Osmanlı Modernleşme Sürecinde "Havadis Jurnalleri" (1840-1844). İstanbul: Türkiye İş Bankası, 2009.

Koçu, Reşat. Tarihimizde Garip Vakalar. İstanbul: Doğan Kitabevi, 2005.

Nugay, Kübra. XIX. Yüzyıl Ortak Ceza Hukuku Dilinin Oluşumu: Osmanlı'da Ta'zîrin Kalkması. İstanbul: Marmara Üniversitesi Sosyal Bilimler Enstitüsü, Doktora Tezi, 2020.

Paz, Omri. "Documenting Justice: New Recording Practices and the Establishment of an Activist Criminal Court System in the Ottoman Provinces (1840-late 1860s)". Islamic Law and Society 21/1-2 (2014), 81-113.

Peters, Rudolph. "Administrators and Magistrates: The Development of a Secular Judiciary in Egypt, $1842-$ 1871”. Die Welt des Islams New Series 39/ 3 (1999), 378-397.

Takvîm-i Vekâyi, (22 Rebîülevvel 1262/ 1846).

Yazıc1, Nesim. "Tanzimat Döneminde Osmanlı Haberleşme Kurumu”. 150. Yllında Tanzimat. haz. Hakk1 Dursun Yıldız. Ankara: Türk Tarih Kurumu Yayınları, 1992.

Yıldırım, Mehmet Zahit. Osmanlı Devleti’nde Jurnal Teşkilatı. İstanbul: AKY Basım, 2012. 


\section{Ekler}

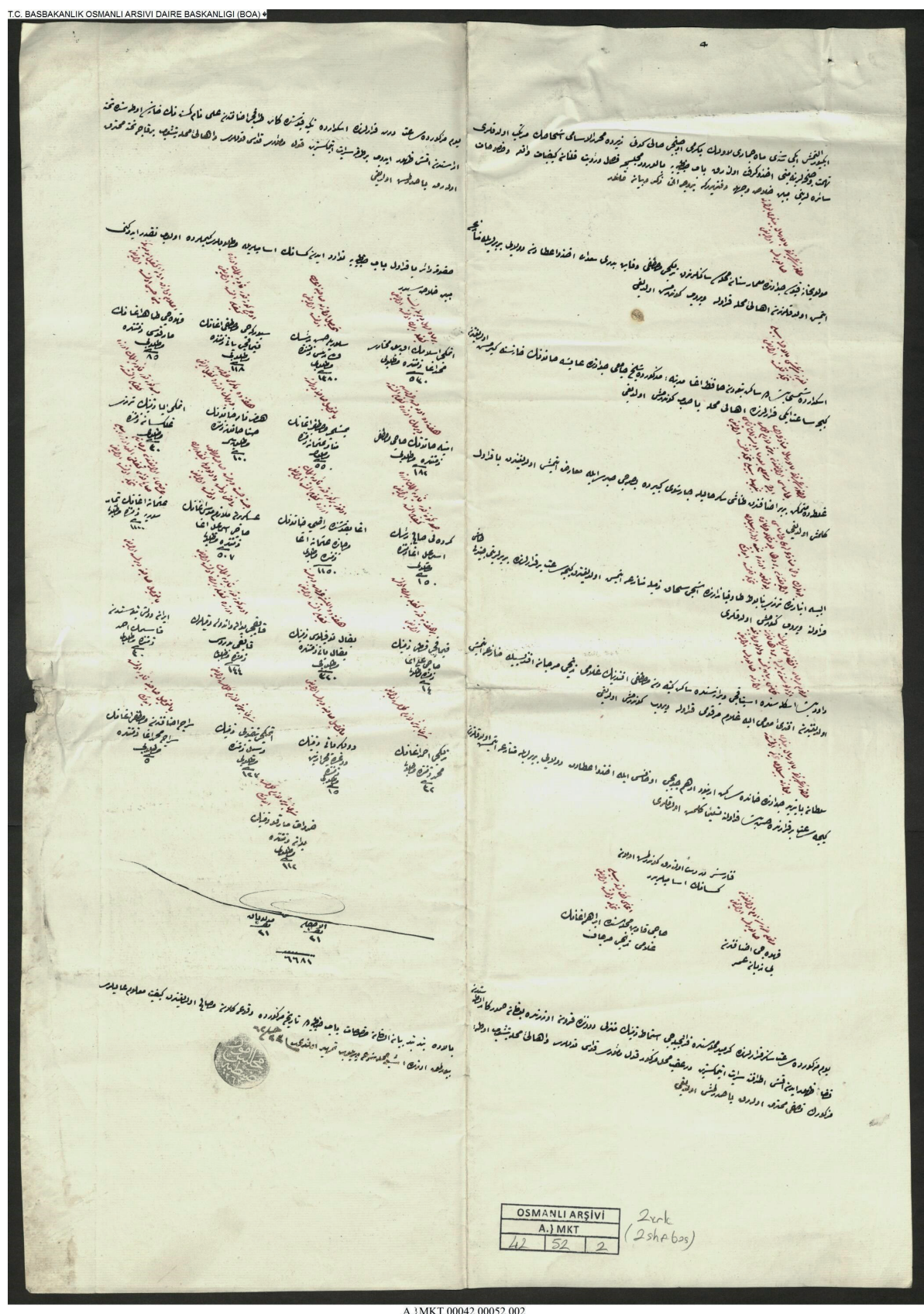

Ek-1: Bâb-1 Zabtiye'den gönderilen jurnal örneği 

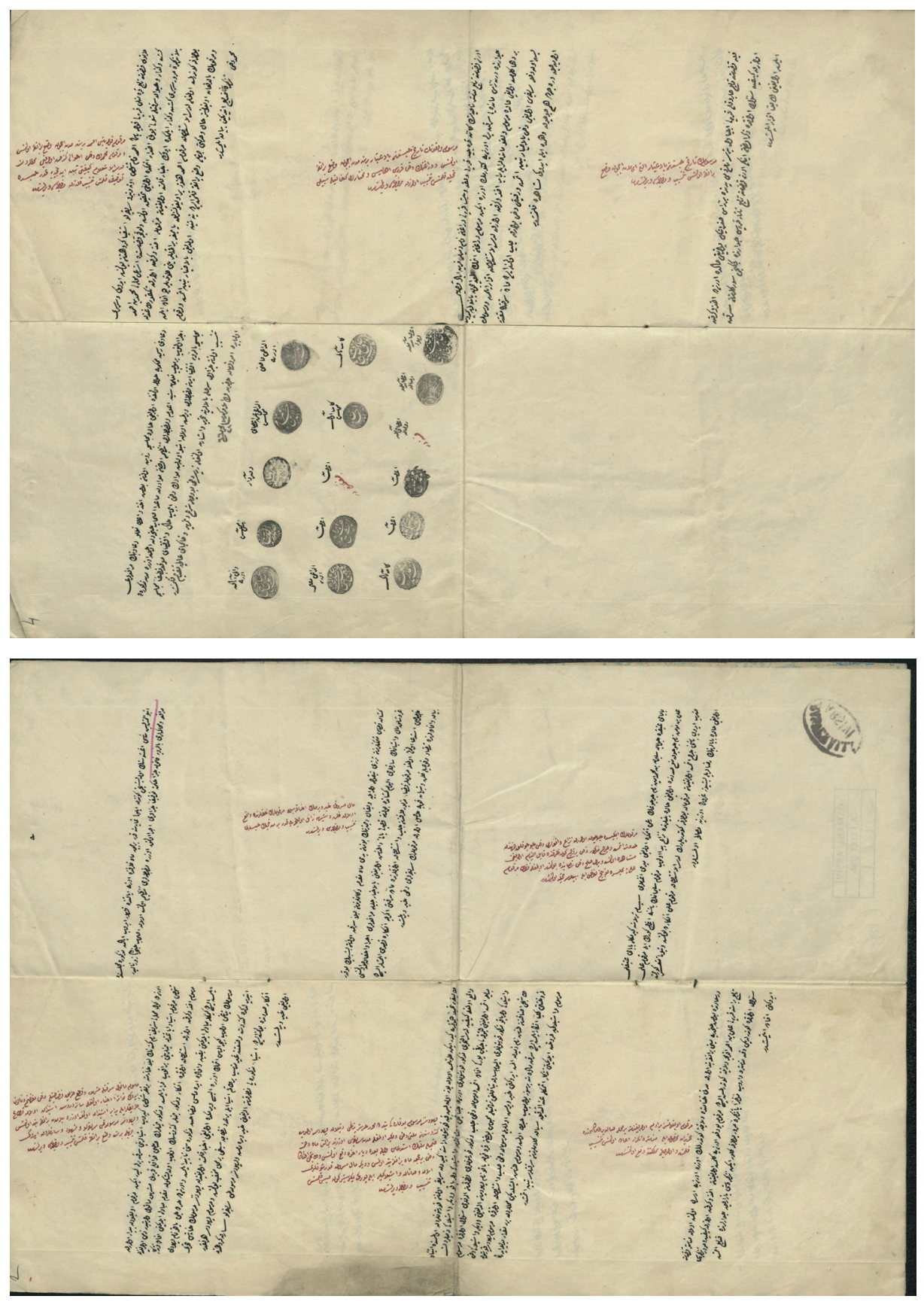

Ek-2: Taşradan gönderilen jurnal örneği 


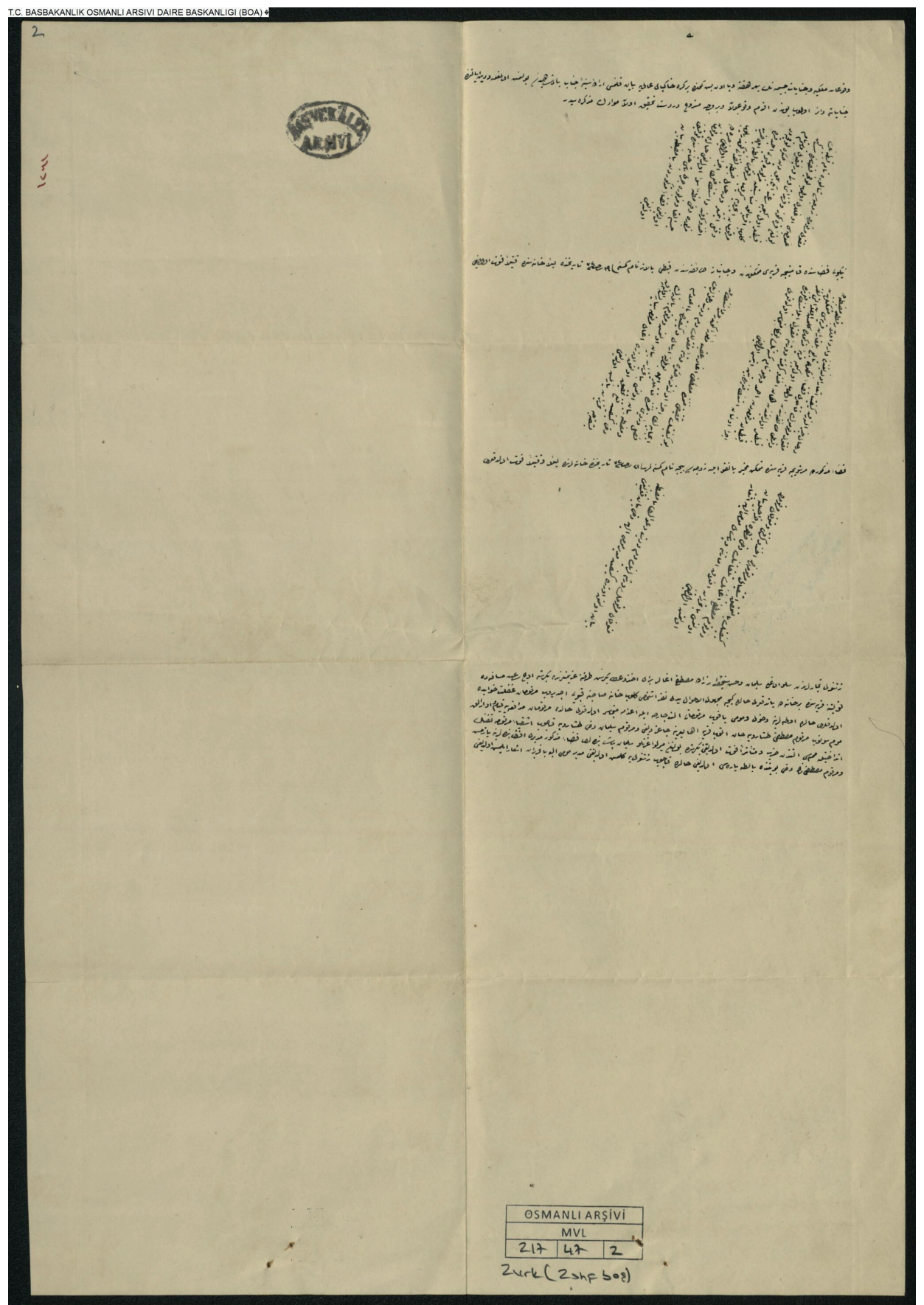

MVL.00217.00047.002

Ek-3: Taşradan gönderilen bir jurnal 


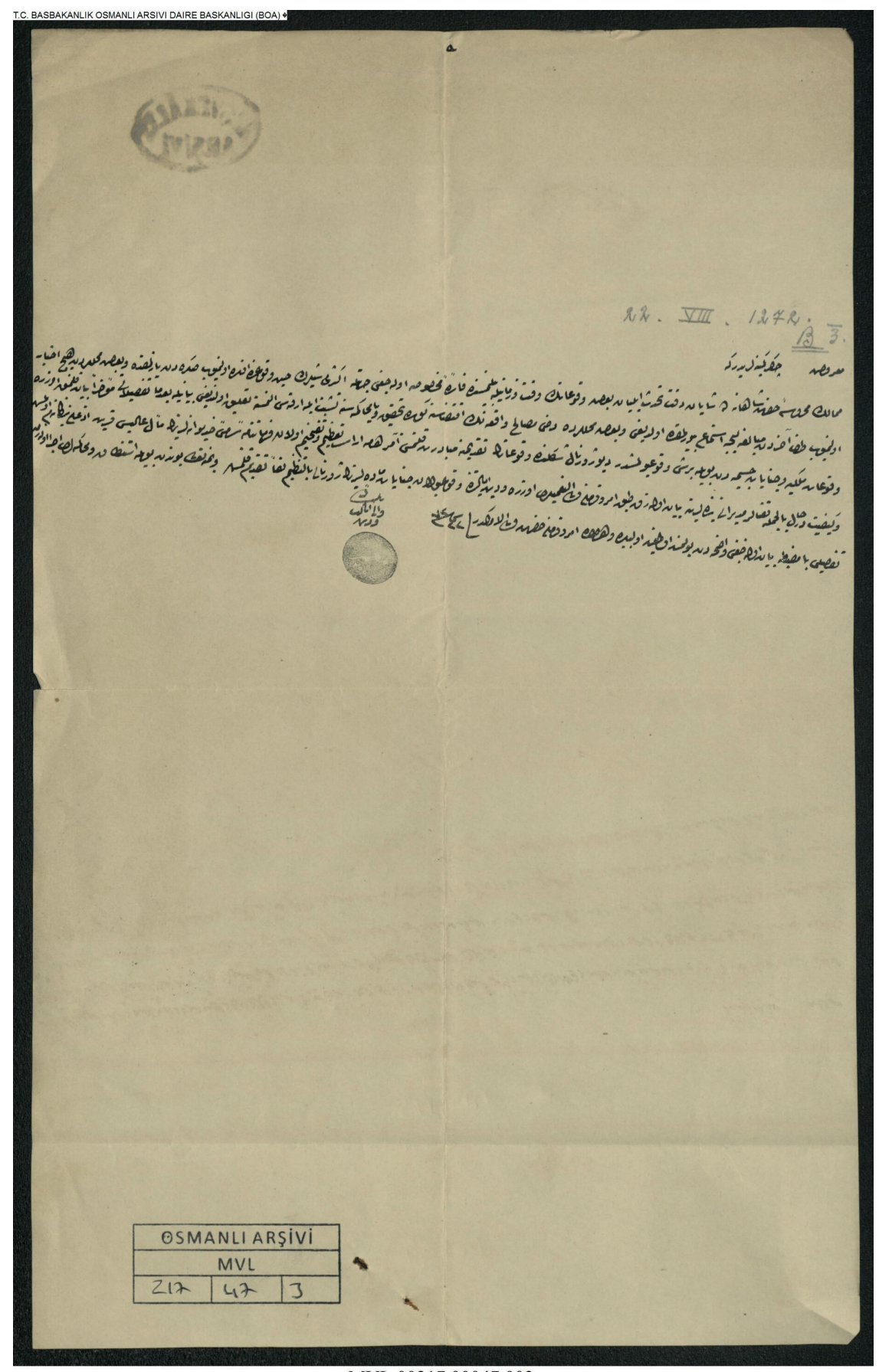

MVL.00217.00047.003

Ek-4: Taşrada bir mecliste hazırlanan jurnale ilgili eyalet valisinin yazdığı tahrîr 


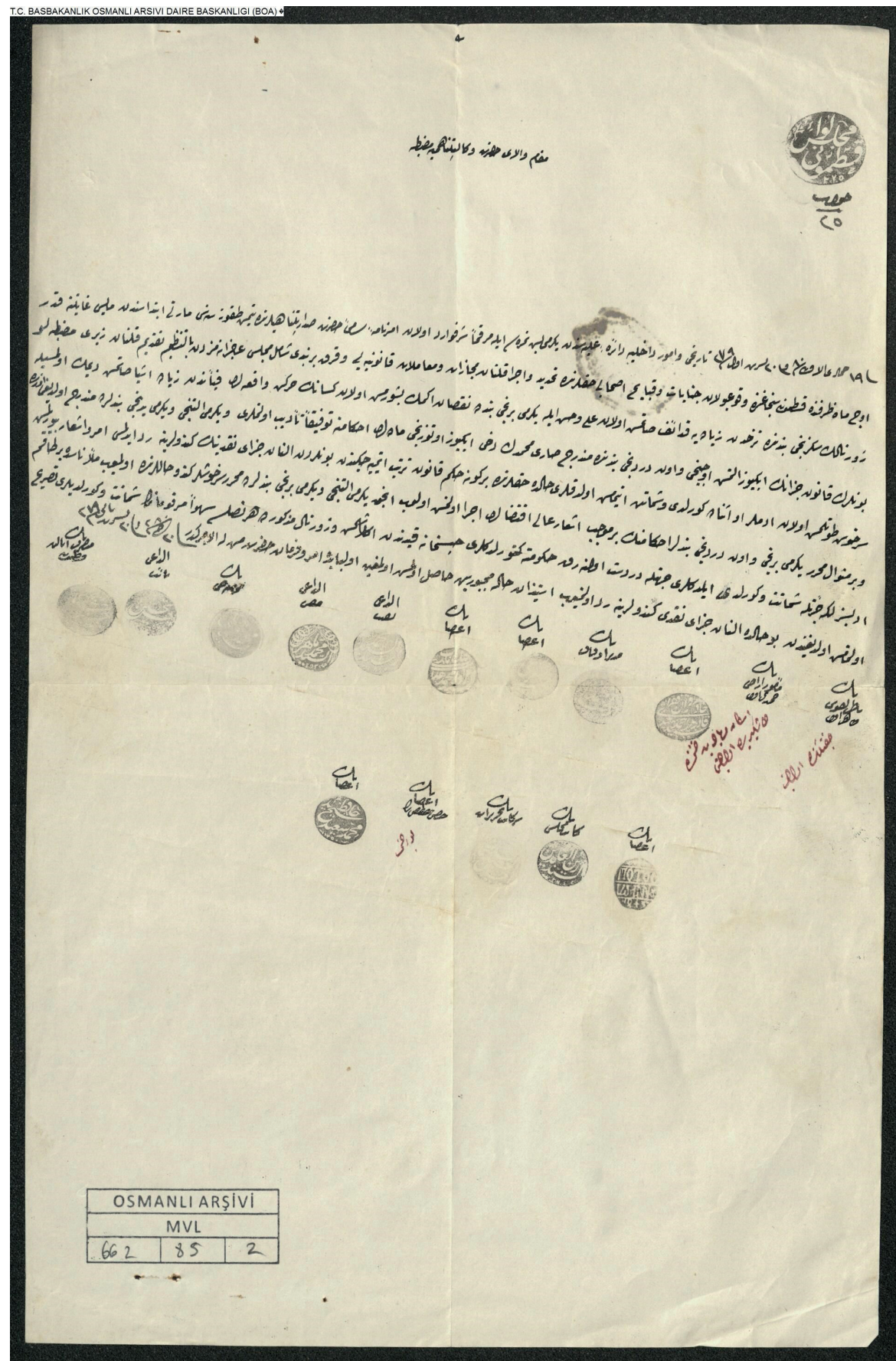

MVL.00662.00085.002

Ek-5: Taşrada bir mecliste düzenlenen jurnale ilgili meclisin hazırladığı mazbata 


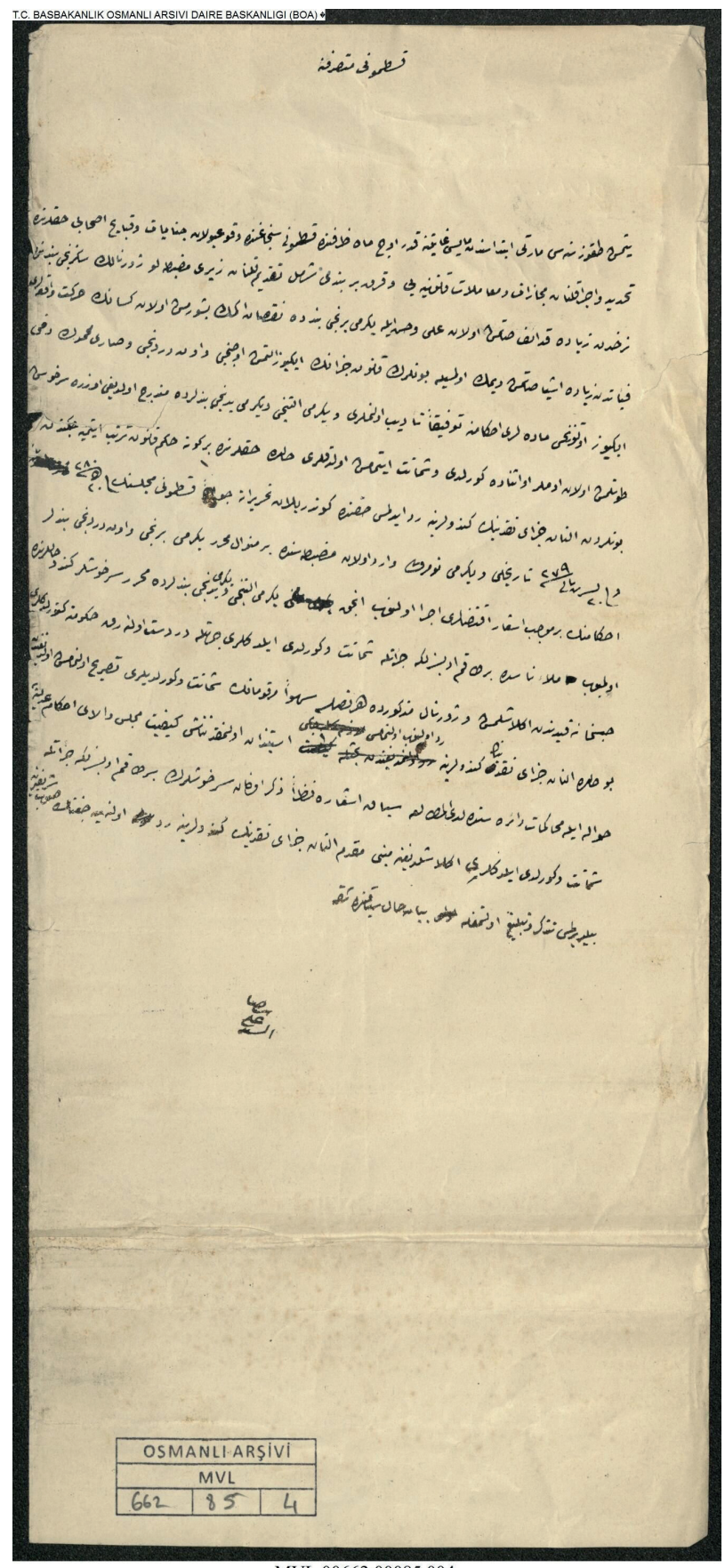

MVL.00662.00085.004

Ek-6: Taşradan gönderilen jurnalin Meclis-i Vâlâ tarafından incelenerek ilgili yerel meclisin bulunduğu eyalet mutasarrıfına/valisine gönderdiği mazbata 


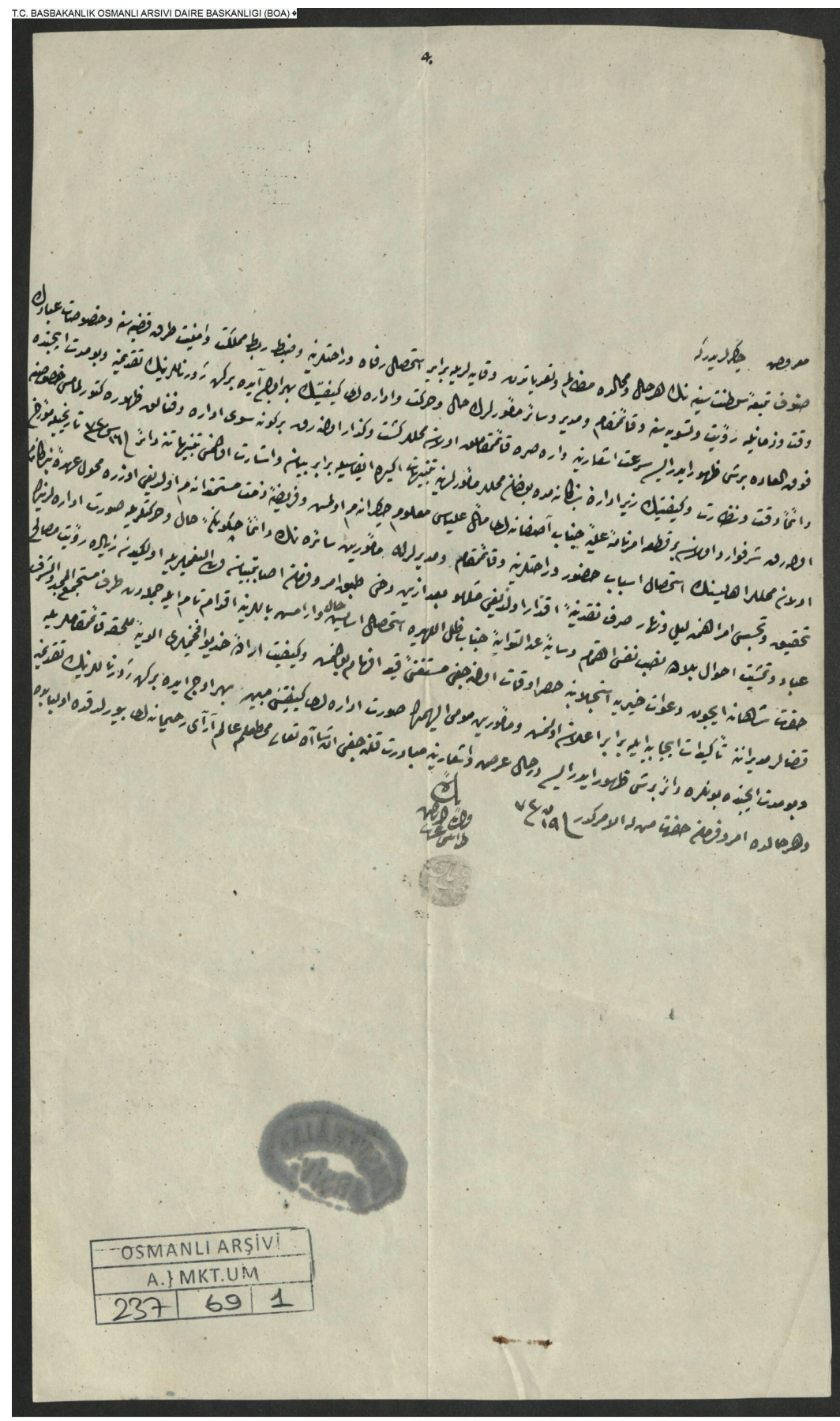

A.\}MKT.UM.00237.00069.001

Ek-7: Emirname üzerine Trablusgarp Valisi'nin gönderdiği tahrîr 
